\title{
Campanian to Maastrichtian palynofacies and dinoflagellate cysts of the Silesian Unit, Outer Western Carpathians, Czech Republic
}

\author{
PETR SKUPIEN \& OMAR MOHAMED
}

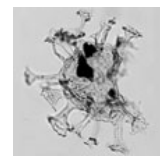

\begin{abstract}
Dinoflagellate cysts are reported from 20 Upper Cretaceous claystone samples from the Godula and Istebna formations of the Silesian unit. Age-assessment of the sediments based on 150 species suggests a Late Campanian to probably earliest Maastrichtian age for the middle and upper part of the Godula Formation and a Early Maastrichtian age for the basal part of the Istebna Formation. Key biotic events are especially the first occurrence datums of Areoligera senonensis, Cerodinium diebelii, Palaeocystodinium golzowense and Trithyrodinium evittii, and the last occurrence datums of Odontochitina, Palaeohystrichophora infusorioides, Raeteiaedinium truncigerum, Trihyrodinium suspectum and Xenascus ceratioides. Palynofacies analysis shows deposition in an offshore marine environment subjected to influxes of terrestrial material. Organic matter is dominated by phytoclasts and contains very little amorphous organic material. The succession is also characterized by a low percentage of dinoflagellate cysts and a very low percentage of spores and pollen grains. The presence of thermophilitic dinoflagellate cysts points to a warm-temperate to subtropical climate during Late Campanian to Early Maastrichtian. - Key words: Silesian Unit, Cretaceous, Campanian, Maastrichtian, dinoflagellate cysts, palynofacies, Carpathians.
\end{abstract}

SKuPIEN, P. \& Mohamed, O. 2008. Campanian to Maastrichtian palynofacies and dinoflagellate cysts of the Silesian Unit, Outer Western Carpathians, Czech Republic. Bulletin of Geosciences 83(2), 207-224 (11 figures, 3 tables). Czech Geological Survey, Prague. ISSN 1214-1119. Manuscript received November 2, 2007; accepted in revised form April 25, 2008; issued June 30, 2008.

Petr Skupien, Institute of Geological Engineering, V̌̌B - Technical University, 17. listopadu 15, Ostrava-Poruba, Czech Republic; petr.skupien@vsb.cz•Omar Mohamed, Geology Department, Faculty of Science, Elminia University, Elminia,Egypt; omaraosman@yahoo.com

The studied sections of marine Upper Cretaceous deposits are situated in the Moravskoslezské Beskydy Mountains, which are part of the Outer Western Carpathians (OWC). Geologically, they belong to Subsilesian and Silesian units of Upper Jurassic to Oligocene hemipelagic and flysch deposits within the OWC nappe system, which overthrusted part of the Carpathian Miocene foredeep and partly on buried Variscides of the Bohemian Massif (Fig. 1). Three fundamentally different facies (developments) are preserved in the present-day structure of the Silesian unit, i.e. the Godula facies (basinal setting); the Baška facies (frontal slope setting); and the Kelč facies (continental slope setting).

The Upper Cretaceous comprises dominantly flysch (turbiditic) sediments belonging to the Godula Formation and Istebna Formation (Fig. 2). The dinoflagellate cyst assemblages described in this paper come from the Stare Hamry, Horní Bečva, Zarovjanka and Bílá sections, which belong to the Godula facies. Twenty samples collected for palynology were studied with special emphasis on the dinoflagellate cyst assemblages.
This study builds on earlier investigations by Skupien (1999, 2003), Skupien \& Vašíček (2003), Skupien et al. (in press), which dealt with the stratigraphic distribution of microplankton species in the Upper Cretaceous of the Silesian unit. Discovery of dinoflagellate cysts in a claystone layer brings new information on age, palaeoenvironment and palaeogeographical position of these deposits.

\section{Geological setting}

The studied sections are situated in the Silesian unit of the OWC flysch zone. The Upper Cretaceous includes the uppermost part of the Lhoty Formation, the Mazák Formation, the Godula Formation and the Istebna Formation (Pícha et al. 2006). Late Cretaceous (Early Cenomanian; Skupien \& Vašíček 2003) sedimentation starts with light gray shales with a few thin intercalations of dark grey shales in the upper Lhoty Formation. The deposits of the 


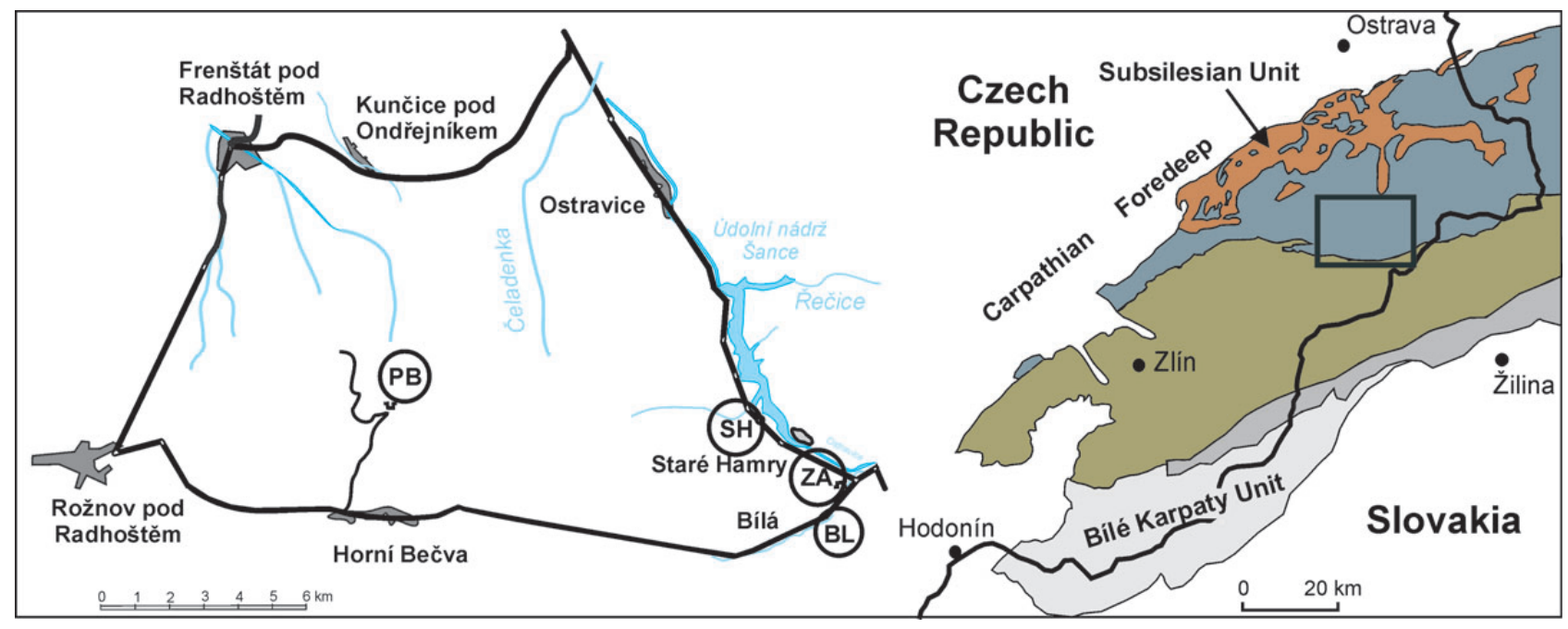

Figure 1. Location map of the studied sections and area in the Outer Western Carpathians. Abbreviations: BL - Bílá section, PB - Horní Bečva section, SH - Staré Hamry section, ZA - Zarovjanka section. — Subsilesian Unit and Ždánice Unit, — Silesian Unit, Bílé Karpaty Unit.

Silesian unit have been studied biostratigraphically using mainly foraminifera; Upper Cretaceous macrofauna are absent.

The Upper Cenomanian to lowermost Coniacian Mazák Formation is represented by sequence of variegated (red, red-brown and grey-green) non-calcareous shales, occasionally interbedded with thin, greenish gray quartzose sandstone layers (Roth 1980, Skupien et al. in press).

The Turonian to Santonian Godula Formation (Hanzlíková 1972a, Menčík et al. 1983) is a typical flysch sequence of alternating sandstones and shales with a variable proportion of these two main lithological components and an overall thickness of more than $3000 \mathrm{~m}$. Lithologically, the formation is subdivided into three parts (Eliás 2000; Matějka 1949, 1952; Menčík et al. 1983): a lower turbiditic facies of thinly bedded glauconitic sandstones and shales (grey, brown-grey, red-grey in colour); middle part with a facies dominated by coarse glauconitic sandstones and conglomerates; and an upper facies of thinly interbedded glauconitic sandstones and shales (grey, green-grey), with coarse sandstones and conglomerates occuring locally.

The Campanian to Maastrichtian to Danian(?) Istebna Formation (Hanzlíková 1972b) developed from the underlying Godula Formation is $1200 \mathrm{~m}$ thick and represented by a typical flysch facies of alternating sequences of arkosic sandstones, slump conglomerates, and sand flows (fluxoturbidites) with an equally thick sequence of dark shales.

The Cenomanian-Early Turonian age of the Mazak Formation was established by the concurrent presence of foraminifers Praeglobotruncana helvetica (Bolli), Praeglobotruncana stephani (Gandolfi) and Rotalipora greenhornensis (Morrow) (Hanzlíková 1973). New data (foraminifera and dinoflagellate cysts) support a Late
Cenomanian to earliest Coniacian age (Skupien et al. in press). Hanzlíková (1972a) described from the Godula Formation foraminiferal assemblages of Turonian to Santonian age. New observation from the continuous Bystrá section (Skupien \& Vašíček 2003, Skupien et al. in press) provided foraminiferal and dinoflagellate cyst assemblages of Coniacian to Early Campanian age in the lower part and of Early to Late Campanian age in the middle part of the formation. Early Campanian to Danian foraminiferal zones were described by Hanzlíková (1972b) from the Istebna Formation.

\section{Material}

Four sections were sampled (Fig. 1). Sample positions are indicated on Figs 3, 4 and 5.

The Stare Hamry section is situated north-east of Trojačka Hill and on the south-western part of the Šance dam. Eleven samples of grey claystones were taken from exposures along the road from Staré Hamry to Ostravice. The studied section consists of thick flysch sediments of the middle part of the Godula Formation (Figs 2A, 3).

The Horní Bečva section is located in an old quarry on the southern side of Kněhyně Hill and about 700 m north of the town Horní Bečva, situated near a sharp turn on the right-hand side of the road from Horní Bečva to Pustevny. Thinly interbedded glauconitic sandstones and shales (grey, green-grey) of the upper part of the Godula Formation are exposed. Three samples were taken from the middle part of the quarry (Figs 2B, 4).

Two samples from the Zarovjanka section were taken from a quarry near the junction of the Bílá Ostravice and Černá Ostravice rivers, north of Bílá. Arkosic sandstones 

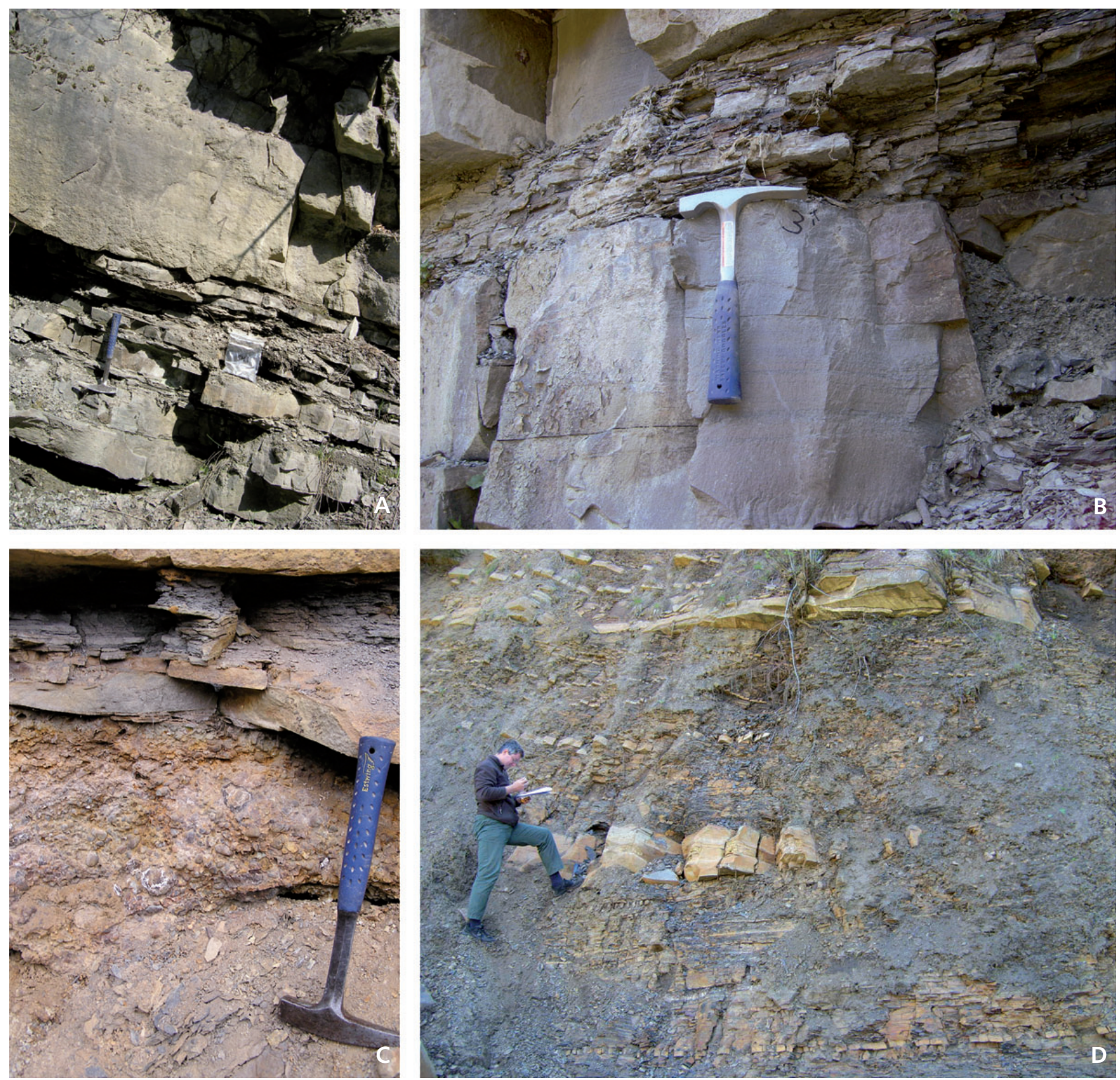

Figure 2. Lithology of the studied sections. $\bullet$ A - thick flysch of the middle part of the Godula Formation, Staré Hamry. B - thin flysch of the upper part of the Godula Formation, Horní Bečva. $\bullet \mathrm{C}$ - slump conglomerates of the basal part of the Istebna Formation, Zarovjanka. $\bullet$ D - dark grey shales with occasional sandstone layers of the Istebna Formation, Bílá.

and slump conglomerates of the basal part of the Istebna Formation are exposed. Samples were taken from the grey to dark grey claystones and siltstones in the middle part of the quarry (Figs 2C).

The Bílá section is located in the south-eastern part of the town Bílá, opposite the old church. Four samples were taken from the exposure on the right bank of the river Bílá Ostravice. The sampled part of the section consists of approximately $9 \mathrm{~m}$ of dark grey shales with occasional sandstone layers of the Istebna Formation (Figs 2D, 5). Shales are rich in organic matter and pyrite.

\section{Methods}

A total of 20 rock samples, mostly recovered from the clay and sandy clay beds, were processed for palynomorphs. After washing and drying, standard processing involved chemical treatment of 15-20 g of sample with $\mathrm{HCl}$ to remove the calcareous fraction and with HF to remove silicates, sieving with an $8 \mu \mathrm{m}$ and $15 \mu \mathrm{m}$ nylon mesh, and centrifuging to concentrate the residues. Oxidation is not used. Two microscope slides were made from each samples using a residue $>8 \mu \mathrm{m}$ for palynofacies analysis. Three sli- 


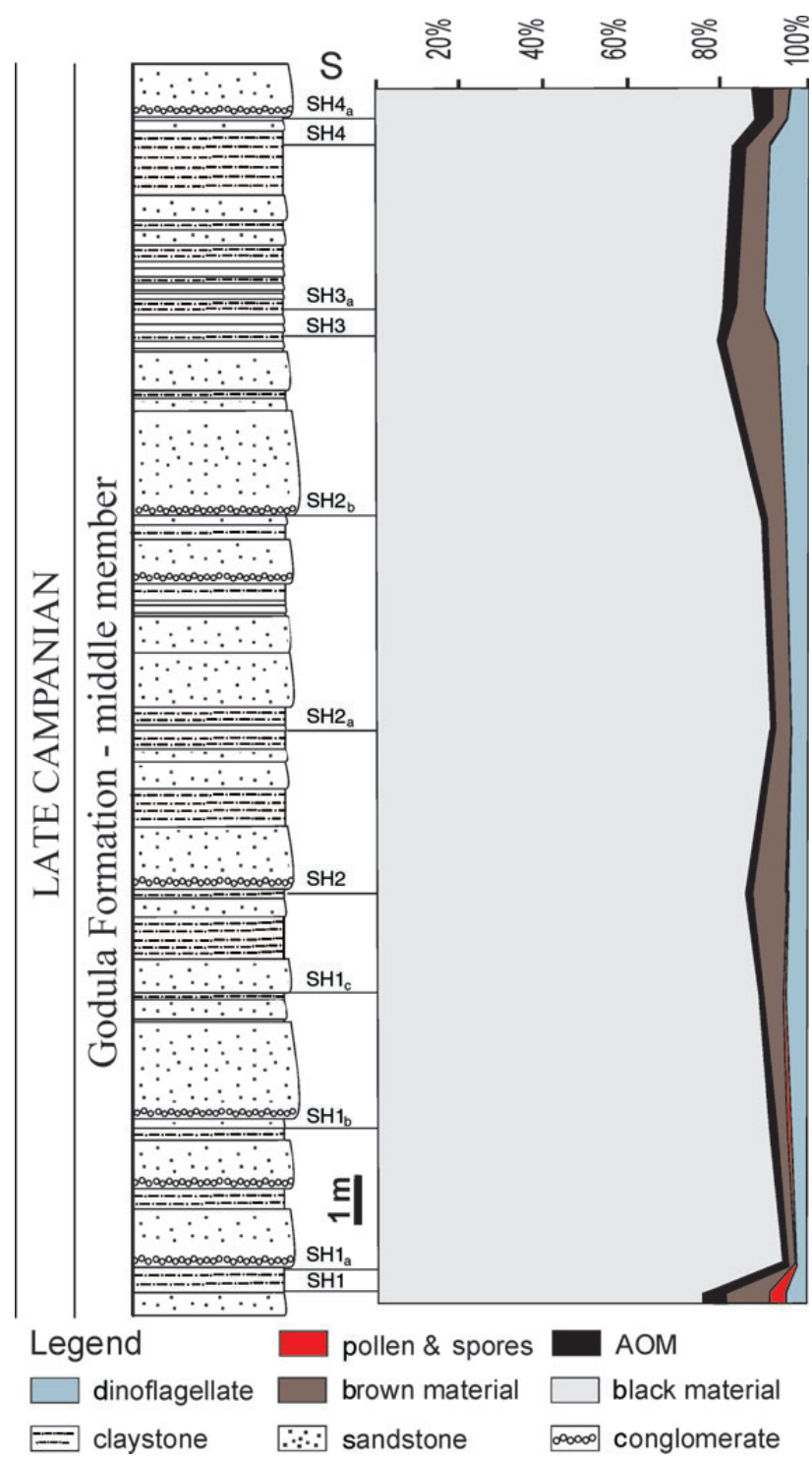

Figure 3. Lithological column with sample position and organic facies composition of the Staré Hamry section. Abbreviation: S - sample.

des were prepared from each sample using a part of the residue $>15 \mu \mathrm{m}$ for dinoflagellate cyst analysis. Whole slides of residues were investigated under a binocular transmitted light microscope to identify and count the palynomorphs and other organic materials. The palynological permanent mounts are stored at the Institute of Geological Engineering at the VŠB - Technical University of Ostrava, Czech Republic. Dinocyst taxa discovered are illustrated and listed in alphabetical order of genus name in an appendix. For dinocyst taxonomy and references to taxa names and authors, please refer to Fensome \& Williams (2004) and Fauconnier \& Masure (2004).

Palynofacies analysis (counting up to 1000 particles) was based on phytoclasts (brown and black material), amorphous organic material (AOM), spores and pollen

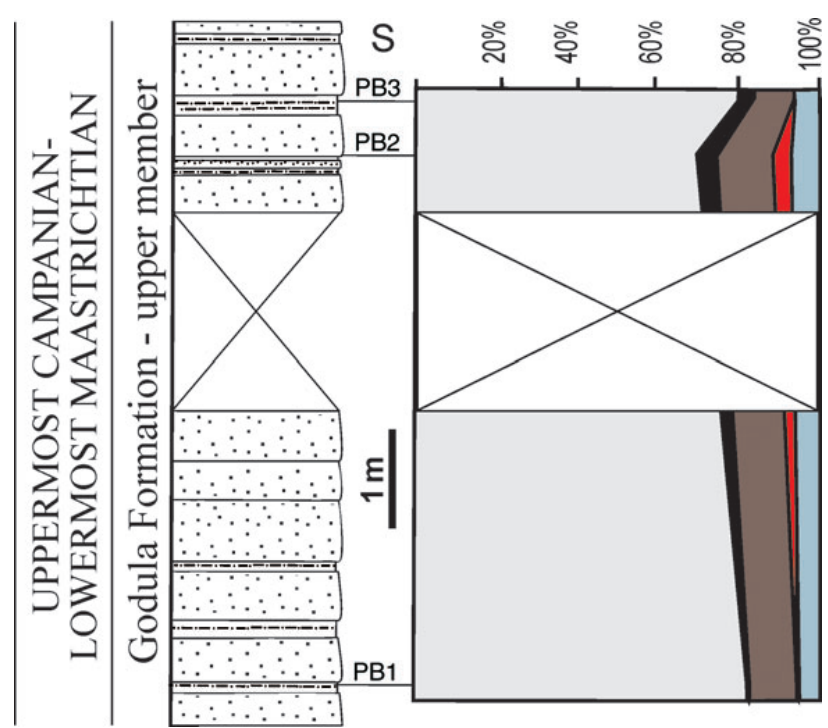

Figure 4. Lithological column with sample position and organic facies composition of the Horní Bečva section.

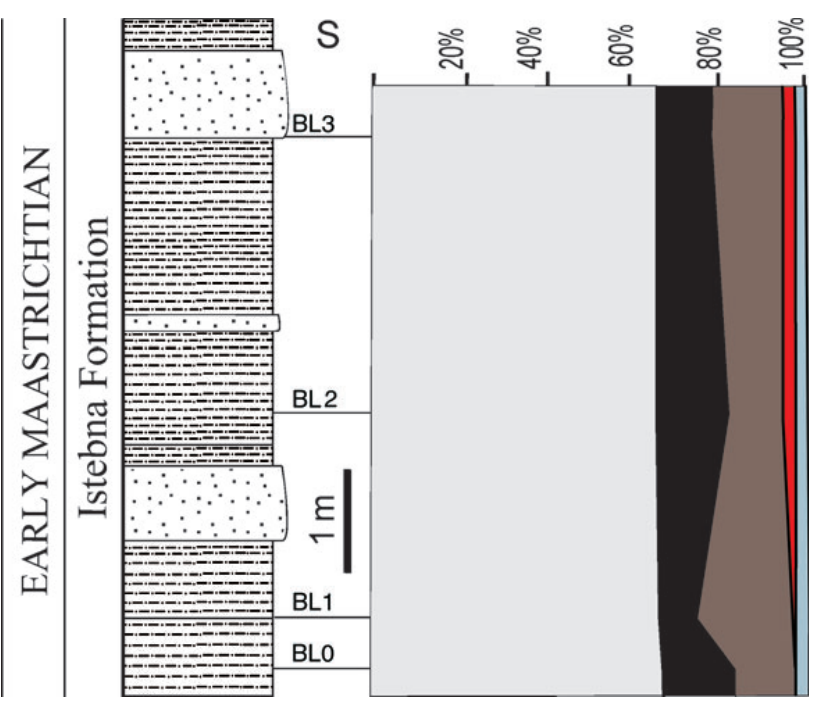

Figure 5. Lithological column with sample position and organic facies composition of the Bílá section.

grains, dinoflagellate cysts and foraminiferal test linnings. The quantitative study included counting of up to 150 determinable dinoflagellate cysts when possible.

\section{Results}

Dinoflagellate cysts have been found in all samples of grey or dark-grey lithofacies. In the present study we identify Late Campanian to Early Maastrichtian dinoflagellate cyst assemblages from the claystone samples (Godula and Istebna formations) in four sections. We also concentrated on the quantitative analysis to interpret the palaeoecology and palaeoenvironment of the studied samples by counting 

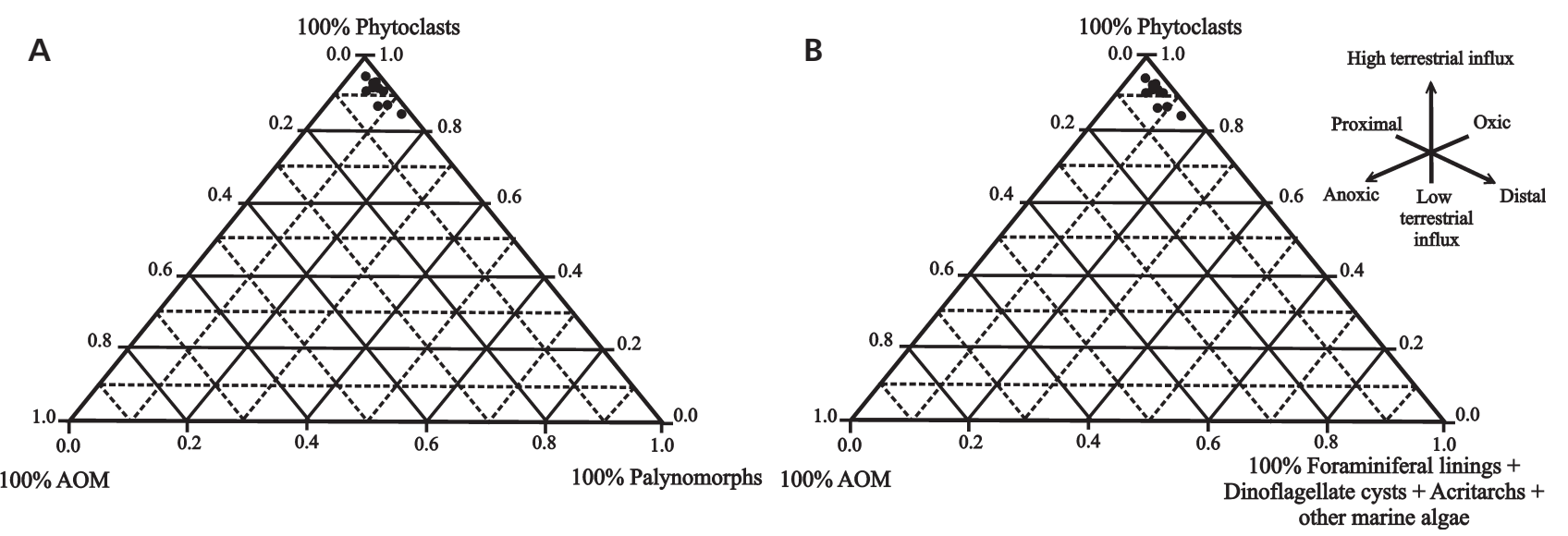

Figure 6. A - AOM-palynomorph (marine and terrestrial) -phytoclast ternary diagram (after Tyson 1995) of the relative numerical particle frequency (\% of the TSOM) in the Staré Hamry section. • B - AOM-phytoclasts-foraminiferal linings/dinoflagellate cysts/acritarchs/other marine algae diagram (modified from Tyson 1995) of the relative numerical particle frequency (\% of the TSOM) in the Stare Hamry section.

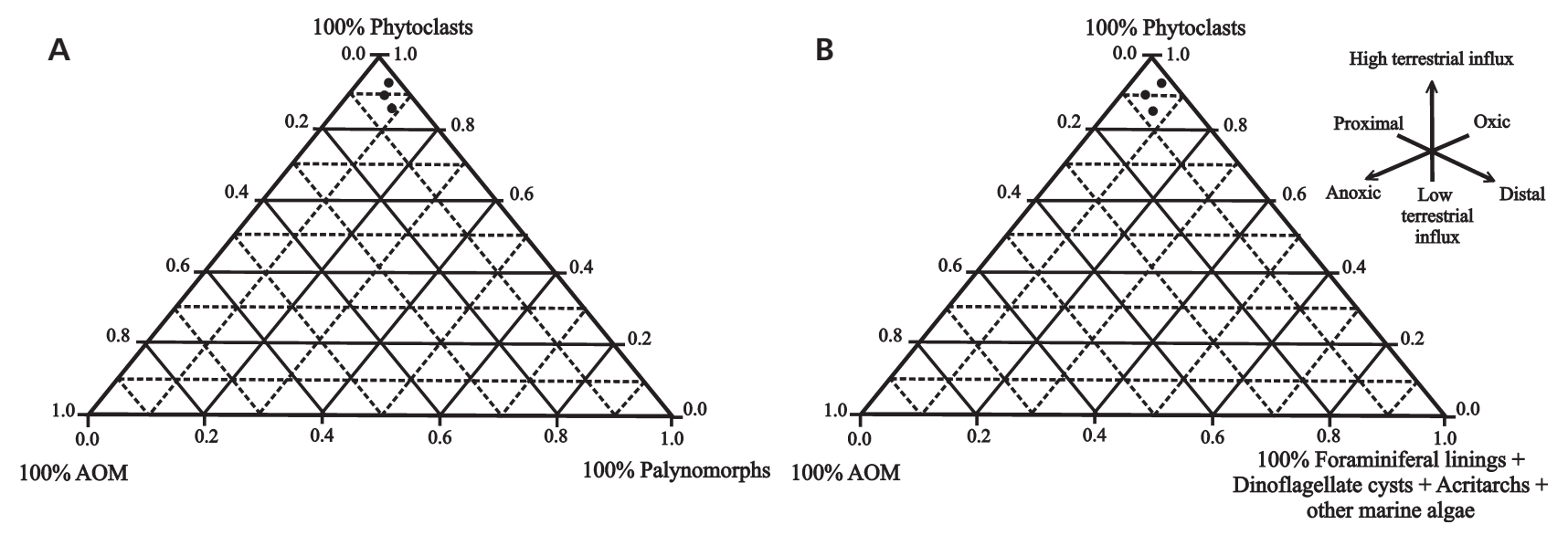

Figure 7. A - AOM-palynomorph (marine and terrestrial)-phytoclast ternary diagram (after Tyson 1995) of the relative numerical particle frequency (\% of the TSOM) in the Horní Bečva section. • B - AOM-phytoclasts-foraminiferal linings/dinoflagellate cysts/acritarchs/other marine algae diagram (modified from Tyson 1995) of the relative numerical particle frequency (\% of the TSOM) in the Horní Bečva section.

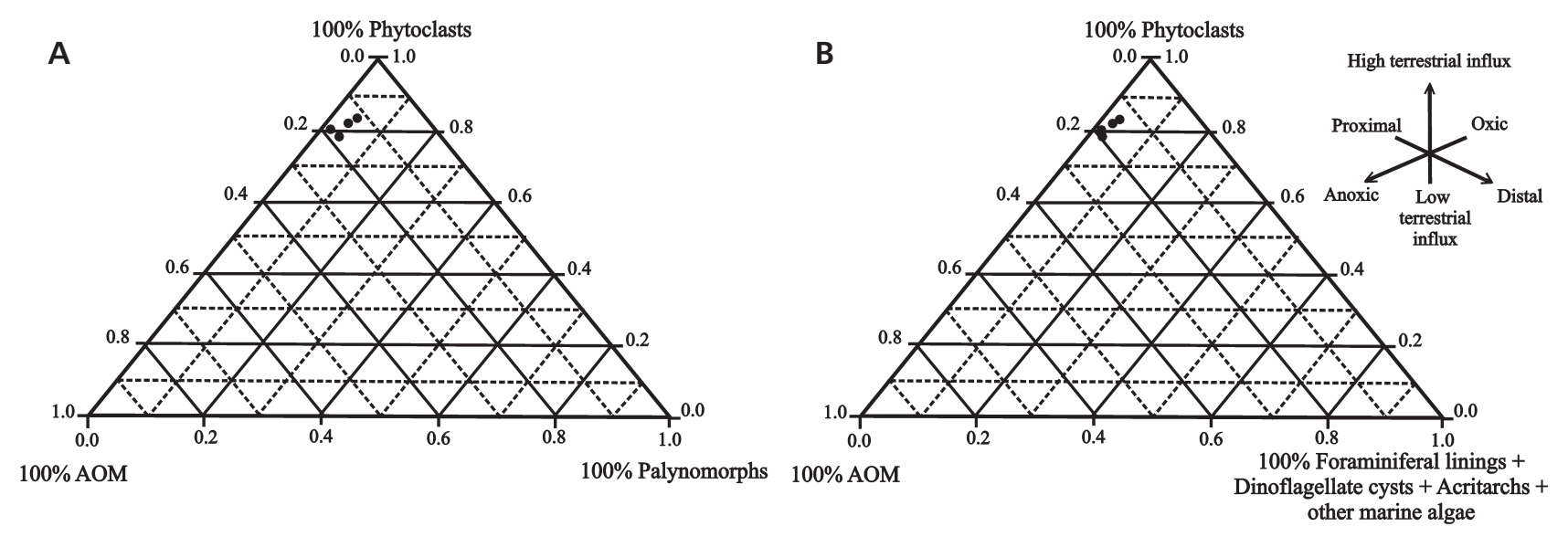

Figure 8. A - OM-palynomorph (marine and terrestrial)-phytoclast ternary diagram (after Tyson 1995) of the relative numerical particle frequency (\% of the TSOM) in the Bílá section. • B - AOM-phytoclasts-foraminiferal linings/dinoflagellate cysts/acritarchs/other marine algae diagram (modified from Tyson 1995) of the relative numerical particle frequency (\% of the TSOM) in the Bílá section. 
Table 1. Distribution of dinoflagellate cysts in the Staré Hamry section. Numbers refer to counted specimens in the slides.

\begin{tabular}{|c|c|c|c|c|c|c|c|c|c|c|c|}
\hline Age & \multicolumn{11}{|c|}{ Late Campanian } \\
\hline Formation & \multicolumn{11}{|c|}{ Godula Formation } \\
\hline Species / Sample Number & SH1 & SH1a & SH1b & SH1c & $\mathrm{SH} 2$ & $\mathrm{SH} 2 \mathrm{a}$ & $\mathrm{SH} 2 \mathrm{~b}$ & $\mathrm{SH} 3$ & $\mathrm{SH} 3 \mathrm{a}$ & SH4 & $\mathrm{SH} 4 \mathrm{a}$ \\
\hline Achomosphaera fenestra & & & 2 & & & 3 & & 3 & 2 & 3 & 2 \\
\hline Achomosphaera ramulifera & 12 & 35 & 30 & & 40 & 16 & & 20 & 30 & 10 & 16 \\
\hline Achomosphaera sagena & & & & & & & & & & 4 & \\
\hline Achomosphaera triangulata & 8 & 43 & 40 & 20 & 46 & 12 & & 21 & 17 & & \\
\hline Areoligera coronata & 16 & & & & & & & & & & \\
\hline Areoligera senonensis & & & 4 & & & & & & & & \\
\hline Biconidinium longissimum & & & & & & & & 2 & & & \\
\hline Callaiosphaeridium asymmetricum & 13 & & 5 & & 17 & 9 & & & & & 7 \\
\hline Cerebrocysta bartonensis & & & & & & & & & & & 1 \\
\hline Cerodinium sp. & 9 & & & & & & & & & & \\
\hline Chatangiella bondarenkoi & 8 & & & & & & & & & & \\
\hline Chatangiella spectabilis & & & & & 7 & 8 & & & 12 & & 5 \\
\hline Chatangiella tripartita & & & & 7 & & 7 & & & & & \\
\hline Chatangiella williamsii & & & & & & & 6 & & & & \\
\hline Cordosphaeridium sp. & & & & & & 1 & & & & & \\
\hline Coronifera oceanica hebospina & & & & & & & 5 & & & & \\
\hline Cribroperidinium orthoceras & 6 & & 5 & 4 & & & & & 5 & & \\
\hline Cyclonephelium distinctum & & & & & 7 & & & 7 & & 9 & \\
\hline Dinogymnium cf. sibiricum & 4 & & & & 2 & & & & & & \\
\hline Dinogymnium sp. & & & 5 & & & & & & & & \\
\hline Downiesphaeridium? aciculare & & 5 & & & 3 & & & 7 & & 4 & \\
\hline Exochosphaeridium bifidum & & & & & 10 & & & & 14 & & \\
\hline Exochosphaeridium aff. bifidum & & & & & 4 & & & & & & \\
\hline Exochosphaeridium multifurcatum & 11 & & & & & & & & & & \\
\hline Exochosphaeridium phragmites & & & & & 7 & & & & & & \\
\hline Exochosphaeridium sp. & & 38 & 40 & 31 & & 46 & & & & & \\
\hline Florentinia aculeata & & & & 8 & & 11 & & & 25 & & 15 \\
\hline Florentinia cooksoniae & & & & 2 & & & & & & & \\
\hline Florentinia deanei & 7 & & & & & & & & 6 & & \\
\hline Florentinia hypomagna & & & 2 & & & & & & & & \\
\hline Florentinia laciniata & & & & & 5 & & & & 6 & & \\
\hline Florentinia sp. & & & 21 & & & & & & & & \\
\hline Glaphyrocysta sp. & & & 1 & & & & & & & & \\
\hline Glaphyrocysta texta & & & & & 2 & & & & & & \\
\hline Hafriasphaeridium fluens & & & 2 & & & & & & & & \\
\hline Hystrichokolpoma proprium & & & & 2 & & 1 & & & 5 & & \\
\hline Hystrichodinium pulchrum & 5 & 7 & & & & & 5 & & & & 6 \\
\hline Hystrichosphaeridium bowerbankii & & 11 & & 24 & 23 & 13 & & 11 & 27 & 21 & 21 \\
\hline Hystrichosphaeridium salpingophorum & & & & & & 4 & & & & & \\
\hline Hystrichosphaeridium tubiferum & & 12 & & & & 8 & 7 & & & 6 & \\
\hline Hystrichosphaeridium sp. & & & & & 5 & & & & & & \\
\hline Hystrichostrogylon membraniphorum & 7 & & & & 10 & 8 & 8 & & & & \\
\hline Isabelidinium belfastense & & & 5 & & & 2 & & & & 1 & \\
\hline Isabelidinium sp. & & & 35 & & & 11 & 11 & 5 & 26 & & \\
\hline Isabelidinium svartenhukense & 4 & & & & & & & & & & \\
\hline Kiokansium polypes & & & & 4 & & & & & & & \\
\hline Kleithriasphaeridium loffrense & & & 22 & & & & & 5 & 15 & & \\
\hline
\end{tabular}


Table 1. Continued

\begin{tabular}{|c|c|c|c|c|c|c|c|c|c|c|c|}
\hline \multirow{3}{*}{$\begin{array}{c}\text { Age } \\
\text { Formation } \\
\text { Species / Sample Number }\end{array}$} & \multicolumn{11}{|c|}{ Late Campanian } \\
\hline & \multicolumn{11}{|c|}{ Godula Formation } \\
\hline & SH1 & SH1a & SH1b & SH1c & $\mathrm{SH} 2$ & $\mathrm{SH} 2 \mathrm{a}$ & $\mathrm{SH} 2 \mathrm{~b}$ & SH3 & $\mathrm{SH} 3 \mathrm{a}$ & SH4 & $\mathrm{SH} 4 \mathrm{a}$ \\
\hline Kleithriasphaeridium readii & & & & & & & & 3 & & & \\
\hline Leberidocysta chlamydata & & & & & & & 1 & & & & \\
\hline Multiplicisphaeridium? cruciatum & & & & & & & & & 3 & & \\
\hline Odontochitina costata & & & & & 2 & 9 & & & 7 & & \\
\hline Odontochitina operculata & 23 & & 29 & 31 & 21 & 4 & & 5 & 17 & & \\
\hline Oligosphaeridium albertense & 5 & & & & & & & & & & \\
\hline Oligosphaeridium complex & & 11 & 15 & 41 & 43 & & & 5 & & & 23 \\
\hline Operculodinium centrocarpum & & & & & & & 1 & & & & \\
\hline Palaeohystrichophora infusorioides & 5 & 6 & & 2 & & & & & & & \\
\hline Palaeoperidinium sp. & & 2 & & & & & & & & & \\
\hline Palaeotetradinium silicorum & & & & & & & & & 2 & & \\
\hline Pervosphaeridium pseudhystrichodinium & & 19 & 68 & 23 & 18 & 17 & & & & & 19 \\
\hline Pervosphaeridium truncatum & & & 11 & 8 & 15 & & & 4 & & & \\
\hline Phelodinium cf. kozlowskii & 1 & & & & & & & & & & \\
\hline Phthanoperidinium distinctum & & & & & & & & 1 & & & \\
\hline Pterodinium aliferum & 1 & & & 1 & & & & 8 & & & 1 \\
\hline Pterodinium cingulatum & 5 & & 1 & & & & & & 1 & & \\
\hline Raetiaedinium truncigerum & & & 1 & & & & & & & & \\
\hline Senoniasphaera inornata & & & & & & & 2 & & & & \\
\hline Senoniasphaera rotundata & 6 & & 5 & & & & & & & & \\
\hline Spiniferites cf. bulloideus & & & 2 & 2 & & 4 & 3 & & & 1 & \\
\hline Spiniferites crassipellis & & & & & & & & & 1 & & \\
\hline Spiniferites membranaceus & & 2 & & & & & & 3 & & & \\
\hline Spiniferites porosus & & & & & & & & & & & 2 \\
\hline Spiniferites ramosus & 31 & 23 & 47 & 13 & 31 & 25 & 10 & 31 & 74 & 11 & 31 \\
\hline Spiniferites ramosus brevifurcatus & 13 & 13 & 16 & & & & & & & 11 & \\
\hline Spiniferites aff. ramosus granomembranaceus & & & & 2 & 12 & 6 & 2 & & 14 & & \\
\hline Spiniferites aff. ramosus granosus & & & & 2 & & & & & & & \\
\hline Subtilisphaera sp. & & & & & & 2 & & & & & \\
\hline Surculosphaeridium? longifurcatum & 31 & 26 & 49 & 21 & 43 & 32 & 20 & 9 & 31 & & \\
\hline Tanyosphaeridium boletus & & & & & & & 2 & & 2 & & \\
\hline Trithyrodinium evittii & & & & & & & & 2 & & & \\
\hline Trithyrodinium sp. & & & & & & & & & 4 & & \\
\hline Trithyrodinium suspectum & 2 & & & & 3 & 2 & & & & & 2 \\
\hline Xenascus ceratioides & 9 & & & & & & & 19 & 7 & 14 & \\
\hline Xenascus sp. & & 22 & & & & & & 10 & & & 11 \\
\hline
\end{tabular}

the total sedimentary organic material (TSOM), as noted above.

Most residues were characterized by abundant sedimentary organic materials (SOM), dominated by phytoclasts (87-96\% in the Staré Hamry section; 85-95\% in the Horní Bečva section; 79-83\% in the Bílá section) and a small percentage of AOM (1-4\% in Staré Hamry section; $1-5 \%$ in Horní Bečva section; up to $17 \%$ in the Bílá section). The succession is also characterized by a low percentage of dinoflagellate cysts (less than 9\%) and a very low percentage of spores and pollen grains (less than 5\%). Overall the studied samples show little vertical variation in the palynofacies (Figs 3-5).

Changes in palynofacies types and composition of palynomorph assemblages can provide information to interpret the depositional environments in terms of water depth, sea-water oscillation, temperature variations and terrigenous influx (Lister \& Batten 1988, Smelror \& Leereveld 1989, Batten 1996). Samples are usually plotted in ternary diagrams. Tyson (1995) suggested the use of 
AOM-Palynomorphs-Phytoclasts (APP) ternary plots to characterize marine depositional facies based on SOM (Figs 6-8).

The middle member of the Godula Formation (Staré Hamry section) is characterized by a high percentage of phytoclasts (87-96\%, Figs 3, 6), a low percentage of palynomorphs $(2-10 \%)$ and a very low amount of AOM (1-4\%). We found only one foraminifer specimen in every $\mathrm{SH} 1,1 \mathrm{c}$ and $2 \mathrm{~b}$ sample, which indicates a shallow marine environment with high terrestrial influx. Also, we identified 87 dinoflagellate cysts species (Table 1) and the assemblages of many samples are rich in species such as Achomosphaera ramulifera, A. triangulata, Cribroperidinium orthoceras, Exochosphaeridium sp., Florentinia aculeata, Hystrichosphaeridium bowerbankii, Hystrichosphaeridium pulchrum, Odontochitina operculata, Oligosphaeridium complex, Pervosphaeridium pseudhystrichodinium, Spiniferites ramosus, Surculosphaeridium? longifurcatum and Xenascus ceratioides.

In the upper member of the Godula Formation (Horní Bečva section, Table 2) we identified 52 dinoflagellate cyst species. Assemblages are characterized by taxa such as Chatangiella spectabilis, Heterosphaeridium spinaconjunctum, Odontochitina operculata, Oligosphaeridium asterigerum, Palaeohystrichophora infusorioides, Spiniferites cf. bulloideus, Spiniferites porosus, Spiniferites ramosus, Surculosphaeridium? longifurcatum, Thalassiphora sp., Trithyrodinium evittii, Xenascus ceratioides and Xenascus sarjeantii. Samples are characterized by a very high percentage of phytoclasts (85-95\%, Figs 4, 7), a low percentage of palynomorphs (5-10\%) and very little AOM (1-5\%), which indicates a shallow marine environment with high terrestrial influx.

In the Istebna Formation (Bílá section, Table 3), 57 dinoflagellate cyst species have been identified, which are dominated by species as Achomosphaera fenestra, Areoligera volata, Cerodinium diebelii, Florentinia radiculata, Glaphyrocysta sp., Hystrichosphaeridium pulchrum, Palaeocystodinium golzowense, Palaeoperidinium pyrophorum, Spiniferites ramosus and Sumatradinium sou- couyantiae. Samples are characterized by a very high percentage of phytoclasts (79-83\%, Figs 5, 8), a very low percentage of palynomorphs (1.5-3.5\%) and a slightly higher percentage of AOM (10-17\%), which indicates a shallow marine environment with high terrestrial influx and near anoxic conditions.

\section{Discussion}

Below we characterize the stratigraphic assignment of the studied sediments according to dinoflagellate cysts (Figs 9-11). Quantitative abundances of dinoflagellate cysts are illustrated in Tables 1, 2 and 3. To determine the age of the strata based on the distribution of dinoflagellate cysts, species ranges were compared with other studies in the Northern Hemisphere (Robaszynski et al. 1985, typeMaastrichtian area; Kirsch 1991, southern Germany; Costa \& Davey 1992, North Sea; Hoek et al. 1996, Israel; Roncaglia \& Corradini 1997, Roncaglia 2002, Torricelli \& Amore 2003, Italy; Antonescu et al. 2001, south-western France). In addition, the oldest and youngest occurrences of dinoflagellate cyst species of Stover et al. (1996) and Williams et al. (2004) were considered.

The dinoflagellate cyst assemblages of the samples of the middle part of the Godula Formation (Staré Hamry section, Table 1) can be assigned to the Late Campanian. Two interesting markers are the first occurrences of the species Areoligera senonensis and Trithyrodinium evittii. The first occurrences of Areoligera senonensis (sample SH1b in the lower part of the Staré Hamry section) are calibrated in the Late Campanian of the Maastrichtian type area (Robaszynski et al. 1985), of southern Germany (Kirsch 1991) and of the northern Apennines (Roncaglia \& Corradini 1997). Trithyrodinium evittii (sample SH3) has the first occurrence in the latest Campanian of south-west France (Antonescu et al. 2001). But the FO of this taxon is usually considered to be a criterion for the earliest Maastrichtian in mid-latitudes (Williams et al. 2004). The FO observed in the Silesian unit can thus represent the evolutionary ap-

Figure 9. Taxa discovered; the species name is followed by sample location and England Finder coordinates (for localization of the specimen on the slide). Scale is $20 \mu \mathrm{m}$. • A - Alterbidium acutulum (Wilson, 1967b) Lentin \& Williams, 1985; ZA1, S28/2. • B - Chatangiella bondarenkoi Vozzhennikova, 1967; SH1/a, U32/3. • C - Callaiosphaeridium asymmetricum (Deflandre \& Courteville, 1939) Davey \& Williams 1966b; Pb1a, K31/32. • D - Cribroperidinium orthoceras (Eisenack, 1958a) Davey 1969a; SH3a/a, K43/2. • E - Achomosphaera sagena Davey \& Williams, 1966; SH4/a, P42/2. • F - Biconidinium longissimum Islam, 1983c; SH3/a, S54/1. • G - Areoligera senonensis Lejeune-Carpentier, $1938 ;$ SH1b/a, K35/3. - H - Chatangiella spectabilis (Alberti, 1959b) Lentin \& Williams, 1976; SH4a/a, R44/1. • I - Cerodinium sp.; PB1/a, P42/1. • J - Cerodinium diebelii (Alberti, 1959b) Lentin \& Williams, 1987; ZA1, L42/3.・K - Achomosphaera fenestra Kirsch, 1991; BL2/b, S38. • L - Areoligera volata Drugg, 1967; BL3/b, R53. • M - Chatangiella williamsii Yun, 1981; SH2b/a, P32/4. • N - Cerodinium cf. wardenense (Williams \& Downie, 1966) Lentin \& Williams, 1987; BL0a, S41. • O - Glaphyrocysta sp.; ZA2/a, D51. • P - Florentinia aculeate Kirsch, 1991; SH2a/c, L37. • Q - Cribroperidinium orthoceras (Eisenack, 1958a) Davey, 1969a; PB3/a, R39. • R - Exochosphaeridium bifidum (Clarke \& Verdier, 1967) Clarke et al., $1968 ;$ SH3a/a, H47/1. - S - Hystrichosphaeridium bowerbankii Davey \& Williams, 1966b; SH1c/a, Q32/4. • T - Glaphyrocysta castelcasiensis castelcasiensis Corradini, 1973; BL0a, K32. • U - Cauveridium membraniphorum (Cookson \& Eisenack, 1962b) Fauconnier \& Masure, 2004; PB3/a, Z46/1. • V - Exochosphaeridium phragmites Davey et al., 1966; SH2/a, D34. • W - Hystrichosphaeridium salpingophorum Deflandre, 1935a; SH2a/c, T50. • X - Glaphyrocysta wilsonii Kirsch, 1991; BL0b, F43. • Y - Deflandrea cf. phosphoritica Eisenack, 1938b; ZA1/a, R42/1. • Z - Exochosphaeridium sp.; SH1a/a, S41. 

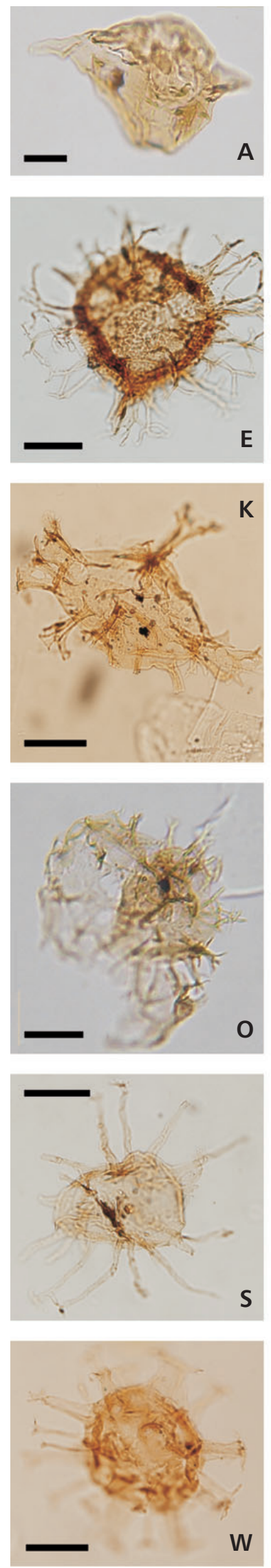
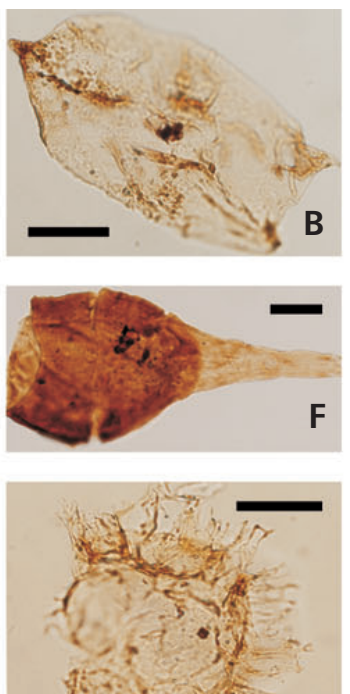

list
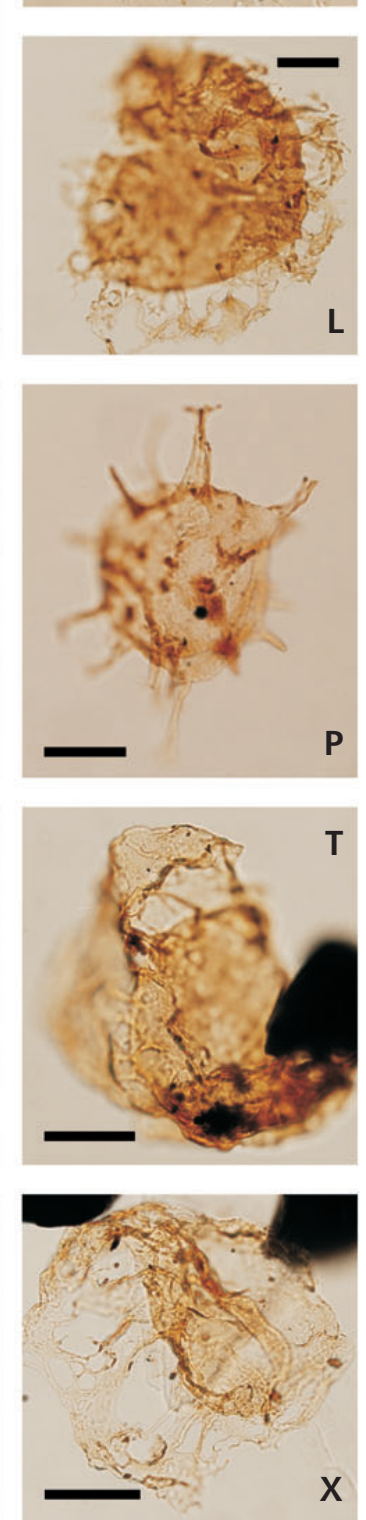
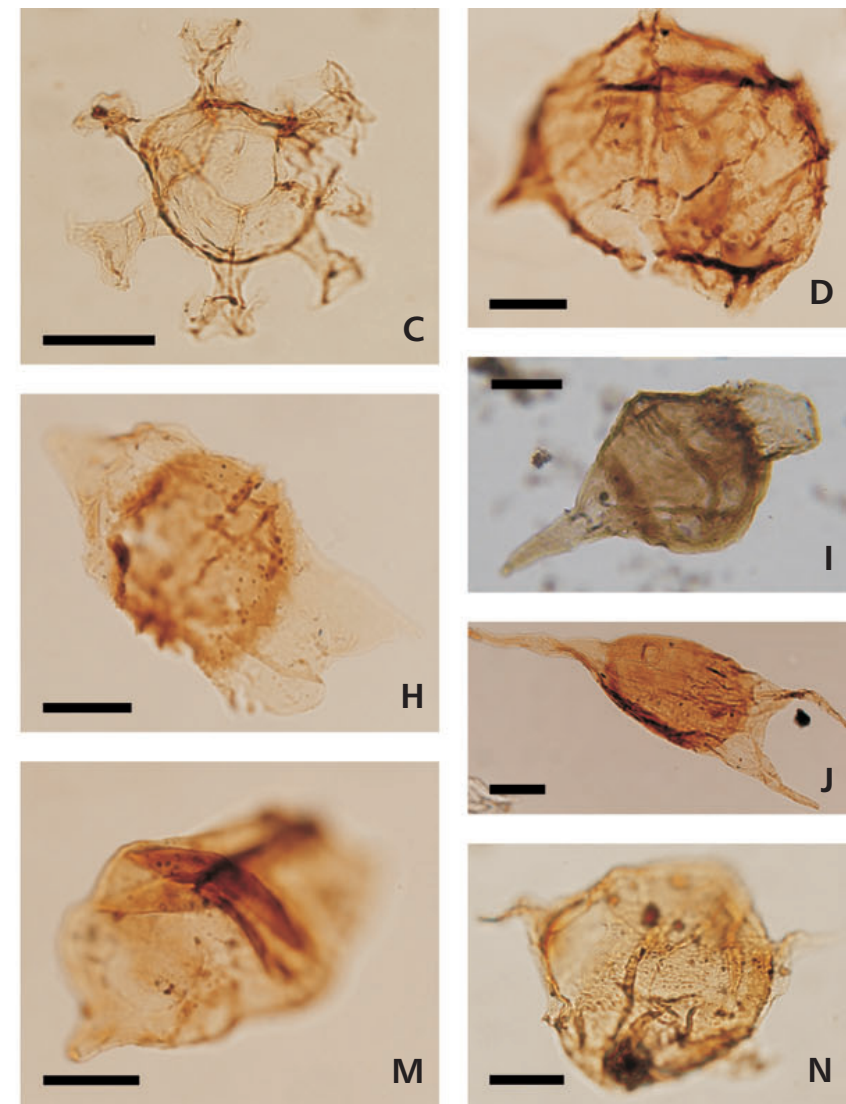

H
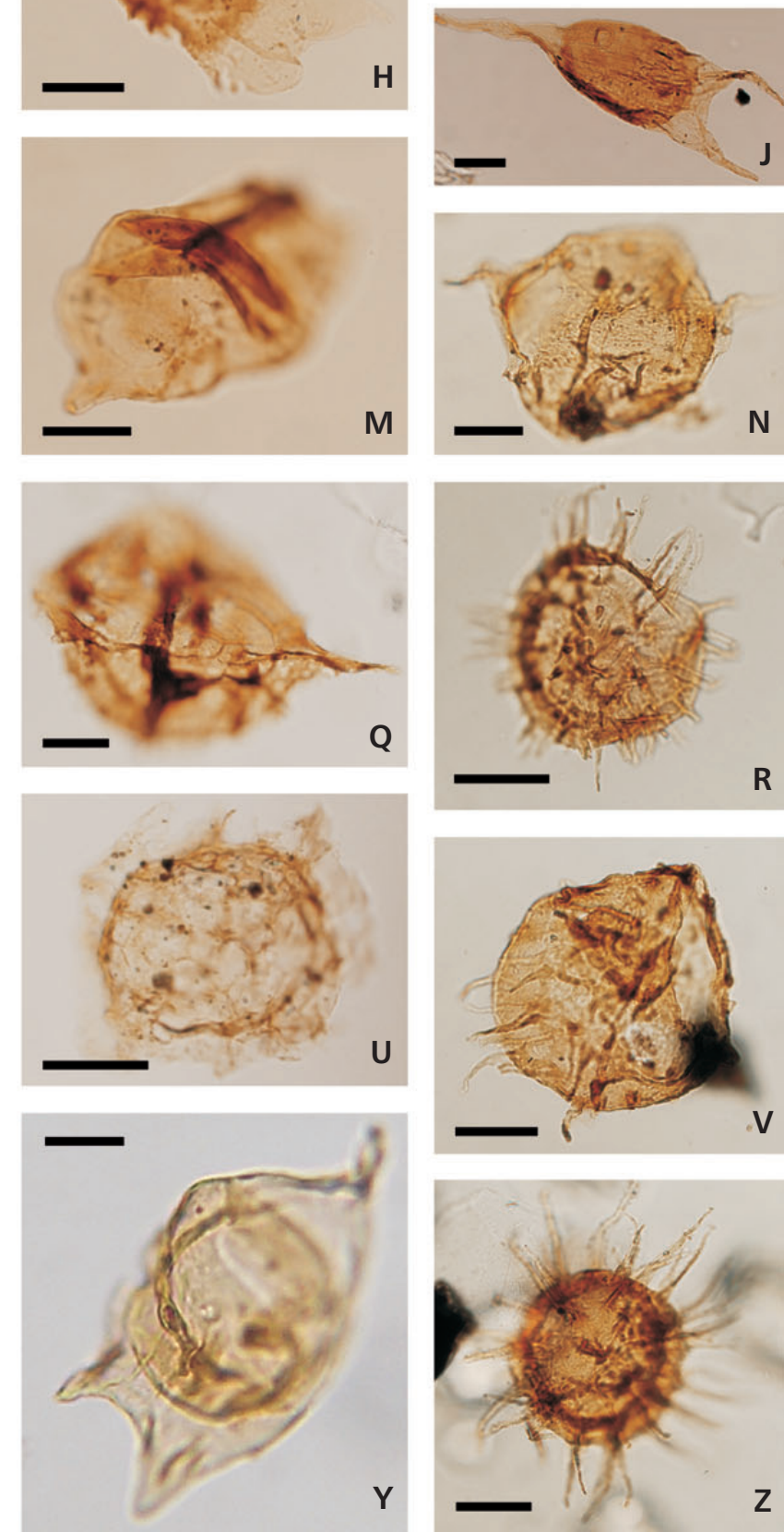
pearance of the taxon in the Western Tethys in accordance with the data of Antonescu et al. (2001).

Other stratigraphically important dinocyst species found are Kleithriasphaeridium loffrense, Raeteiaedinium truncigerum, Senoniasphaera rotundata and Trihyrodinium suspectum. The last occurrences of Kleithriasphaeridium loffrense, Raetiaedinium truncigerum and Senoniasphaera rotundata are Late Campanian (Williams et al. 2004). Antonescu et al. (2001) reports the LO of Raetiaedinium truncigerum slightly above the Campanian/Maastrichtian boundary. In southern Germany the last occurrence of $T$. suspectum is close to the Campanian/Maastrichtian boundary (Kirsch 1991) and in the Northern Hemisphere its total stratigraphical distribution ranges slightly higher into the earliest Maastrichtian (Stover et al. 1996, Williams et al. 2004).

Co-occurrence of these dinocyst species suggests that sedimentation of the middle part of the studied Godula Formation took place during the Late Campanian. This is in accordance with data from the Bystrá section (Skupien et al. in press) where dinoflagellate cyst associations of Middle to Late Campanian age were found, and occurrences of agglutinated foraminifera confirm this age assignment (Skupien et al. in press).

Samples of the upper part of the Godula Formation (Horní Bečva section, Table 2) yield diverse Late Cretaceous dinoflagellate cyst assemblages, including the first appearance of Alterbidinum ulloriaq and Palaeocystodinium golzowense in the Silesian unit. The first occurrences of these species are known from the Early Maastrichtian (Antonescu et al. 2001, Kirsch 1991, Roncaglia 2002). P. golzowense is the index species for the $P$. golzowense Interval Subzone of Roncaglia \& Corradini (1997) in Italy. Only Hoek et al. (1996) have described this species from the Late Campanian in Israel.

Several dinocyst species from the Horní Bečva section are long ranging with stratigraphic range tops limited to the earliest Early Maastrichtian (e.g., Odontochitina costata,
Palaeohystrichophora infusorioides, Xenascus ceratioides, X. sarjeantii; Roncaglia \& Corradini 1997, Robaszynski et al. 1985, Stover et al. 1996, Williams et al. 2004).

Consistent with trends in the composition of the dinoflagellate cyst assemblages throughout the studied sections, the section Horní Bečva indicates an age close to the Campanian/Maastrichtian boundary or probably earliest Maastrichtian.

A Late Campanian - earliest Maastrichtian age of the basal part of the Istebna Formation (Zarovjanka section, Table 3) is confirmed by the presence of Cerodinium diebelii and Palaeocystodinium golzowense. The first occurrence of $C$. diebelii and its related forms (Ypes 2001) is close to the Campanian/Maastrichtian boundary (Antonescu et al. 2001, Kirsch 1991, Roncaglia 2002). Williams et al. (2004) reported that worldwide total distribution of ranges of $C$. diebelii is earlier in the Campanian. This is also the bed that yielded several specimens of Cyclonephelium filoreticulatum, a dinoflagellate cyst described from the Early Maastrichtian (Costa \& Davey 1992), and rich occurrence of Alterbidinium (A. acutulum, A. distinctum), a genus that characterises the Maastrichtian (Antonescu et al. 2001). Hence, depending on the range interpretation of $C$. filoreticulatum and Alterbidinium, an Early Maastrichtian age of the beginning of the Istebna Formation sedimentation in this area of the Silesian basin can be suggested. The latter interpretation coincides with the absence of taxa such as Palaeohystrichophora infusorioides, Odontochitina sp., Xenascus ceratioides with last occurrence in the uppermost Campanian. Their last occurrence was observed in the Horní Bečva section.

Dark grey shales of the Istebna Formation (Bílá section, Table 3) represent the Lower Maastrichtian, as indicated by the presence of Alterbidinium distinctum, Apteodinium deflandrei, Areoligera volata, Hystrichodinium pulchrum, Odontochitina operculata, Trihyrodinium suspectum and genus Glaphyrocysta.

Figure 10. Taxa discovered; the species name is followed by sample location and England Finder coordinates (for localization of the specimen on the slide). Scale is $20 \mu \mathrm{m}$. • A - Hystrichodinium pulchrum Deflandre, 1935a; SH2b/a, K27/4. • B - Odontochitina operculata (O. Wetzel, 1933a) Deflandre \& Cookson, 1955; SH2/a, R35. • C - Kleithriasphaeridium readii (Davey \& Williams, 1966b) Davey \& Verdier, 1976; SH3/b, M41. • D Operculodinium echigoense Matsuoka, 1983b; BL1/b, G40/4. • E - Hystrichosphaeridium? sp.; SH2/a, N33. • F - Isabelidinium belfastense (Cookson \& Eisenack, 1961a) Lentin \& Williams, 1977a; SH2a/c, O42.・G - Isabelidinium cf. bakeri (Deflandre \& Cookson, 1955) Lentin \& Williams, 1977a; PB1/b, T43. • H - Odontochitina costata Alberti, 1961; SH2a/c, Q39/4.・ I - Operculodinium divergens (Eisenack, 1954b) Stover \& Evitt, 1978; BL1/a, P42/4. • J - Florentinia cooksoniae (Singh, 1971) Duxbury, 1980; SH1c/a, R39. • K - Hystrichokolpoma proprium (Marheinecke, 1992) Foucher, 2004; SH2a/c, L38/2. • L - Odontochitina porifera Cookson, 1956; PB1/b, G44/4. • M - Oligosphaeridium albertense (Pockock, 1962) Davey \& Williams, 1969; SH1, S49. • N - Surculosphaeridium? longifurcatum (Firtion, 1952) Davey et al., 1966; SH1/a, O47/2. • O - Pervosphaeridium pseudhystrichodinium (Deflandre, 1937b) Yun, 1981; PB1/b, L47/1. • P - Palaeocystodinium golzowense Alperti, 1961; BL3/a, K50. • Q - Palaeocystodinium golzowense Alperti, 1961; BL0/b, C29/1. • R - Oligosphaeridium buciniferum Corradini, 1973; BL0c, Q36/4. • S - Senoniasphaera rotundata Clarke \& Verdier, 1967; SH1/b, S39.・T - Pervosphaeridium truncatum (Davey, 1969a) Below, 1982a; SH3/b, M41.・U - Pterodinium cingulatum (O. Wetzel, 1933b) Below, 1981a; SH3a/a, R37. • V - Palaeoperidinium pyrophorum (Ehrenberg, 1838) Sarjeant, 1967b; BL0/b, R28. • W - Spiniferites pseudofurcatus (Klumpp, 1953) Sarjeant, 1970; BL3/a, D48. X - Phelodinium cf. kozlowskii (Górka, 1963) Lindgren, $1984 ;$ SH1/b, Q49. - Y - Palaeotetradinium silicorum Deflandre, 1936b; SH3a/b, S39/1. • Z - Palaeohystrichophora infusorioides Deflandre, 1935; SH1a, H44/45. 

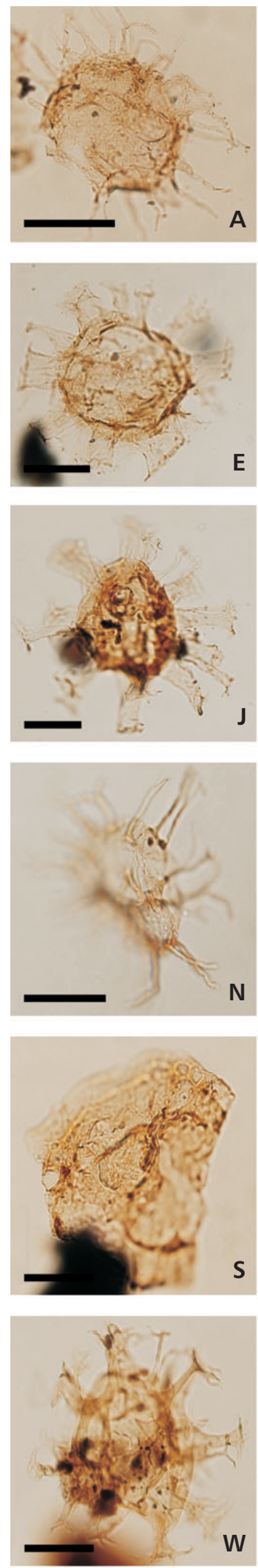
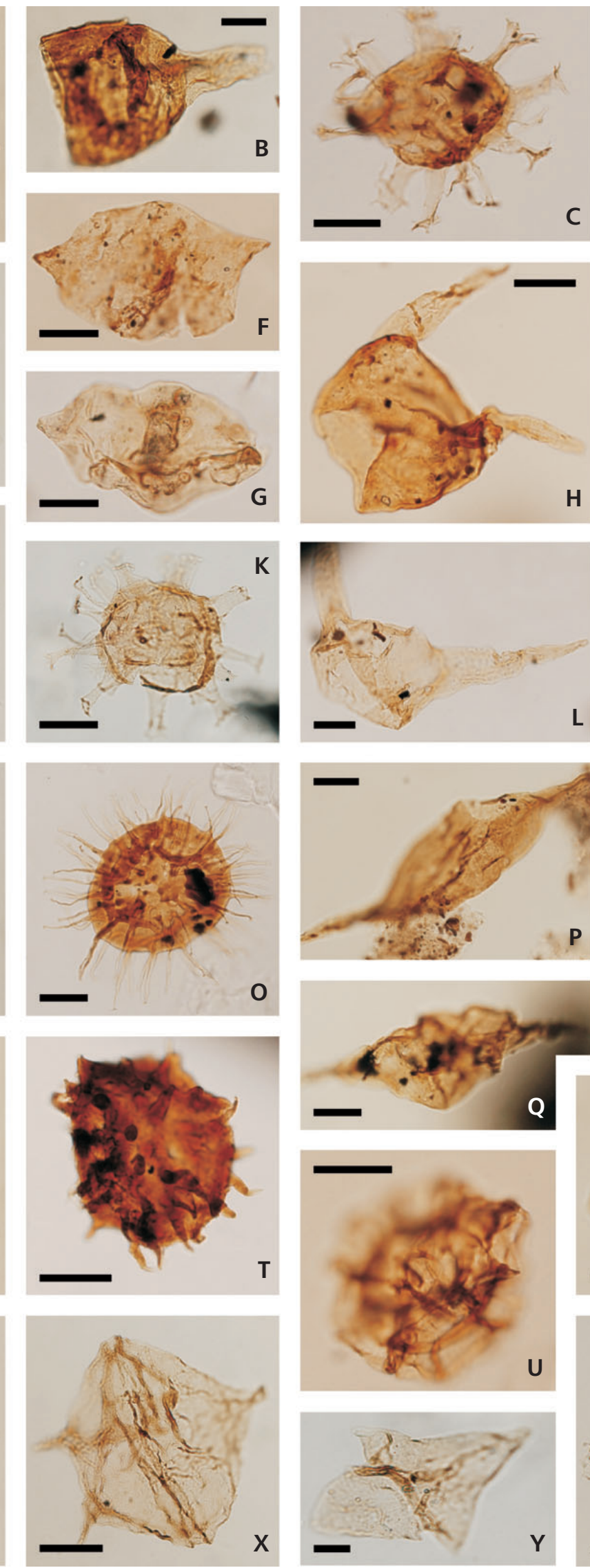
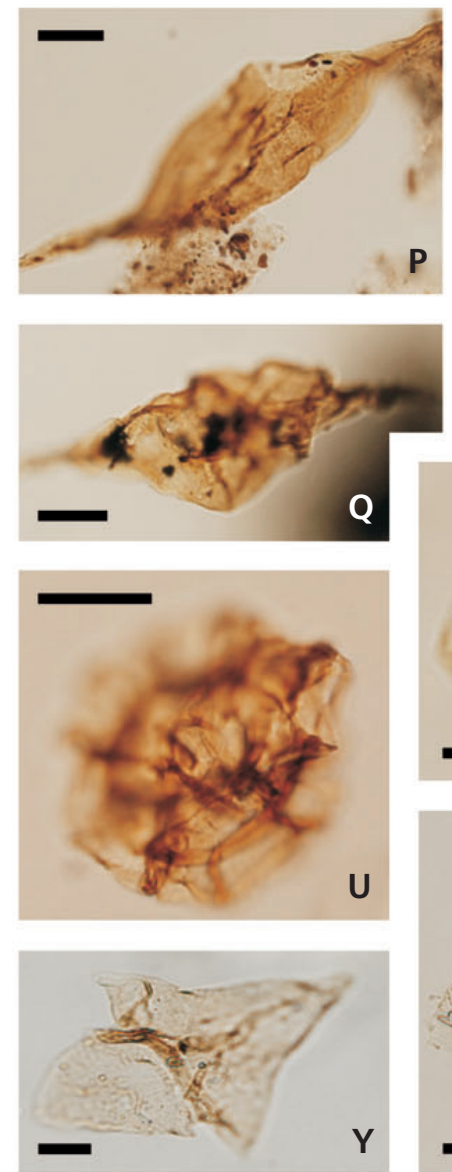
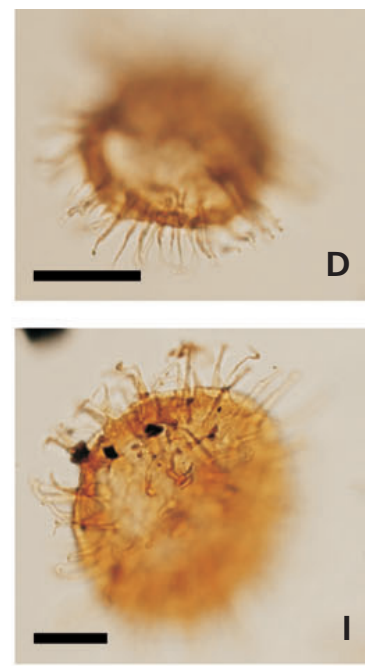

H
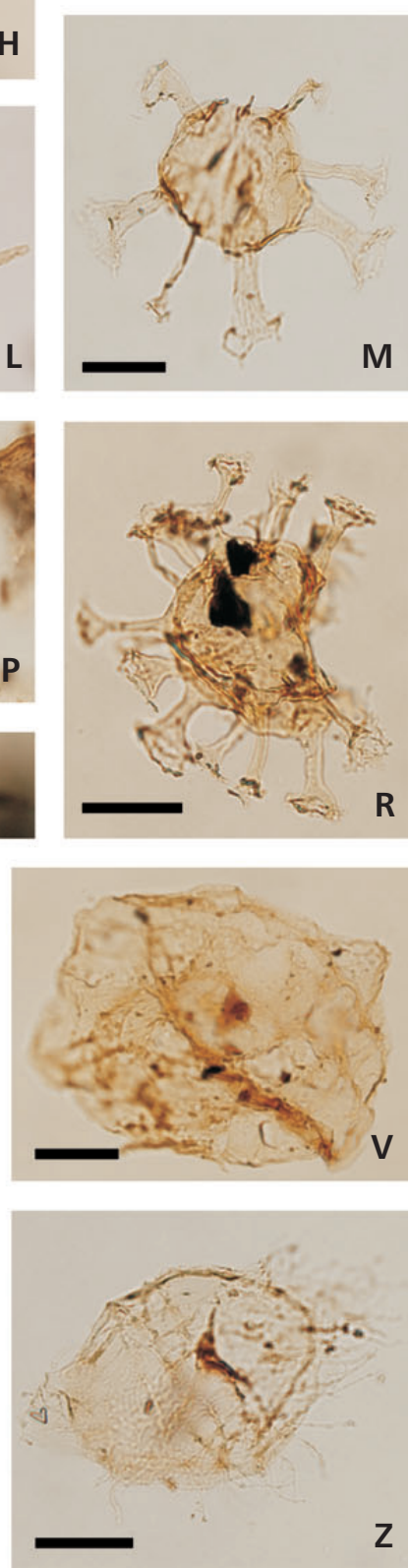
Table 2. Distribution of dinoflagellate cysts in the Horní Bečva section. Numbers refer to counted specimens in the slides.

\begin{tabular}{|c|c|c|c|}
\hline Age & \multicolumn{3}{|c|}{$\begin{array}{c}\text { Uppermost } \\
\text { Campanian-Lowermost } \\
\text { Maastrichtian }\end{array}$} \\
\hline Formation & \multicolumn{3}{|c|}{ Godula Formation } \\
\hline Species / Sample Number & PB1 & PB2 & PB3 \\
\hline Achomosphaera alcicornu & 6 & & \\
\hline Achomosphaera andalousiensis & 6 & 3 & \\
\hline Achomosphaera ramulifera & 32 & & 3 \\
\hline Achomosphaera ramulifera ramosasimilis & & & 16 \\
\hline Achomosphaera triangulata & 11 & 17 & 18 \\
\hline Alterbidinium ulloriaq & 3 & & \\
\hline Callaiosphaeridium asymmetricum & 11 & & \\
\hline Cerodinium sp. & 3 & & 12 \\
\hline Chatangiella spectabilis & 11 & 6 & \\
\hline Cordosphaeridium $\mathrm{sp}$. & & & 6 \\
\hline Cribroperidinium cf. edwardsii & & & 5 \\
\hline Cauveridium membraniphorum & & & 3 \\
\hline Dapsillidinum duma & 2 & & \\
\hline Ellipsodinium rugulosum & & & 2 \\
\hline Florentinia aculeata & 11 & & 12 \\
\hline Heteraulacacysta porosa & 3 & & \\
\hline Heterosphaeridium cordiforme & 15 & & \\
\hline Heterosphaeridium spinaconjunctum & 23 & & 24 \\
\hline Hystrichodinium pulchrum & 8 & & 5 \\
\hline Isabelidinium cf. bakeri & 14 & & \\
\hline Odontochitina costata & & 3 & 4 \\
\hline Odontochitina operculata & 7 & 5 & 8 \\
\hline Odontochitina porifera & 3 & & \\
\hline Oligosphaeridium asterigerum & 4 & 3 & \\
\hline Oligosphaeridium poculum & 3 & & \\
\hline Oligosphaeridium sp. & & & 16 \\
\hline
\end{tabular}

Alterbidinium distinctum was found in sample BL0. Representatives of the genus Alterbidinium have their first occurrence in the Early Maastrichtian (Antonescu et al. 2001). Apteodinium deflandrei has its last occurrence in the Early Maastrichtian (Roncaglia 2002, Williams et al. 2004). Areoligera volata was previously reported from the Maastrichtian of south Germany (Kirsch 1991). The highest occurrences of Hystrichodinium pulchrum and Odontochitina operculata are calibrated in the Early Maastrichtian both in the northern Apennines (Roncaglia 2002, Roncaglia \& Corradini 1997) and in the Maastrichtian type-area (Robaszynski et al. 1985). The highest occurrence of Odontochitina is accepted as a cosmopolitan "event", which has often been reported in the Early Maastrichtian (Wiliams et al. 2004). Trihyrodinium suspectum has its last occurrence in sample BL0 of the studied sections. Representatives of this species do not range beyond the lowermost Maastrichtian (Williams et al. 2004, and others).

\begin{tabular}{|c|c|c|c|}
\hline Age & \multicolumn{3}{|c|}{$\begin{array}{c}\text { Uppermost } \\
\text { Campanian-Lowermost } \\
\text { Maastrichtian }\end{array}$} \\
\hline Formation & \multicolumn{3}{|c|}{ Godula Formation } \\
\hline Species / Sample Number & PB1 & PB2 & PB3 \\
\hline Operculodinium centrocarpum & 6 & & \\
\hline Palaeocystodinium golzowense & & & 5 \\
\hline Palaeohystrichophora infusorioides & 4 & 4 & \\
\hline Palaeoperidinium pyrophorum & & & 11 \\
\hline Pervosphaeridium pseudhystrichodinium & 4 & & \\
\hline Pervosphaeridium truncatum & & & 4 \\
\hline Pierceites cf. schizocystis & 2 & & \\
\hline Senoniasphaera inornata & 13 & & 19 \\
\hline Spiniferites cf. bulloideus & 3 & 4 & \\
\hline Spiniferites porosus & & 3 & 2 \\
\hline Spiniferites pseudofurcatus & & & 11 \\
\hline Spiniferites ramosus & 23 & 9 & 19 \\
\hline $\begin{array}{l}\text { Spiniferites ramosus } \\
\text { granomembranaceus }\end{array}$ & & & 14 \\
\hline Spiniferites scabrosus & & & 2 \\
\hline Spiniferites? velatus & & & 3 \\
\hline Surculosphaeridium sp. & & & 36 \\
\hline Surculosphaeridium? longifurcatum & 7 & 8 & 5 \\
\hline Tehamadinium sp. & & & 7 \\
\hline Thalassiphora sp. & 3 & 1 & \\
\hline Trithyrodinium evittii & 1 & 1 & \\
\hline Trithyrodinium sp. & & & 13 \\
\hline Trithyrodinium suspectum & & & 1 \\
\hline Xenascus ceratioides & 22 & 7 & 2 \\
\hline Xenascus perforatus & 6 & & \\
\hline Xenascus sarjeantii & 11 & 7 & 15 \\
\hline
\end{tabular}

In summary, interpretation of our data suggests that sedimentation of the middle and upper parts of the Godula Formation in the studied part of the Silesian basin is Late Campanian in age and was presumably terminated during the earliest Maastrichtian. Based on earlier data (Skupien et al. in press), sedimentation of the Godula Formation starts in the Santonian. This is in contradiction with the Turonian to Santonian age suggested by Hanzlíková (1972a) based on agglutinated foraminifera. Similarly, Lemanska \& Gedl (2005) interpreted a Late Santonian to Middle Campanian age for the Godula Formation in the Silesian Unit in Poland based on dinoflagellate cysts and foraminifera.

The age of the Istebna Formation was previously interpreted as Campanian to Maastrichtian or Danian(?) (Hanzlíková 1972b). We propose herein a latest Campanian, or possibly Early Maastrichtian age (in comparison with data from Italy, Roncaglia 2002) for the basal sedimentation of the Istebna Formation. 

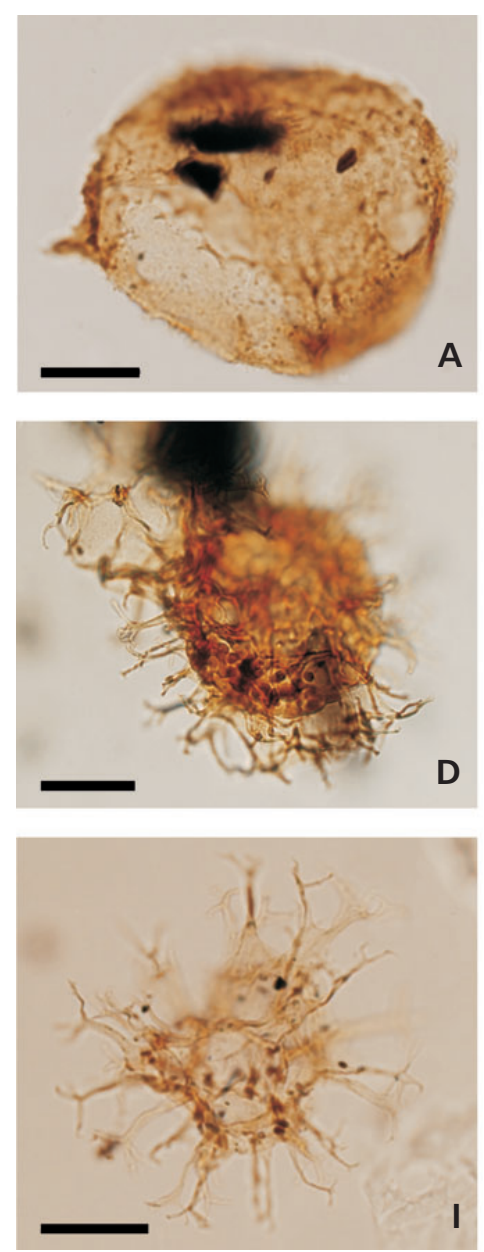
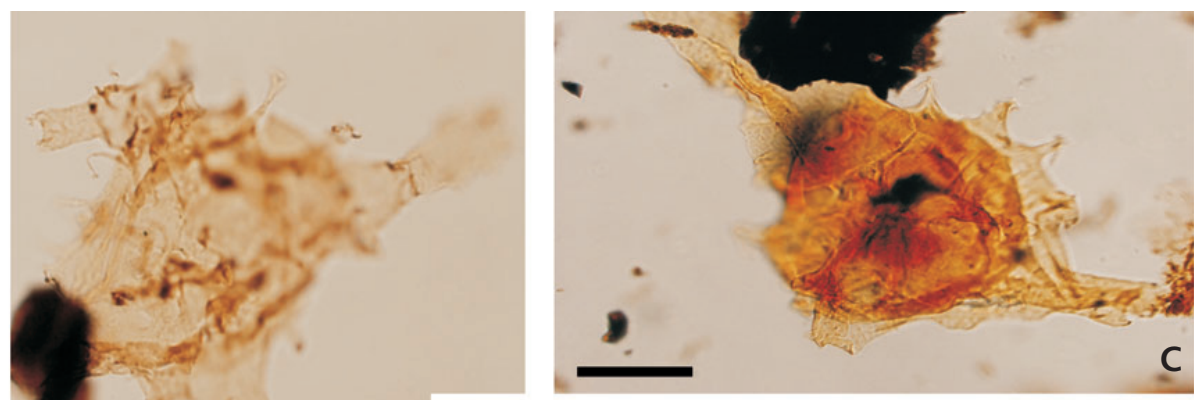

B
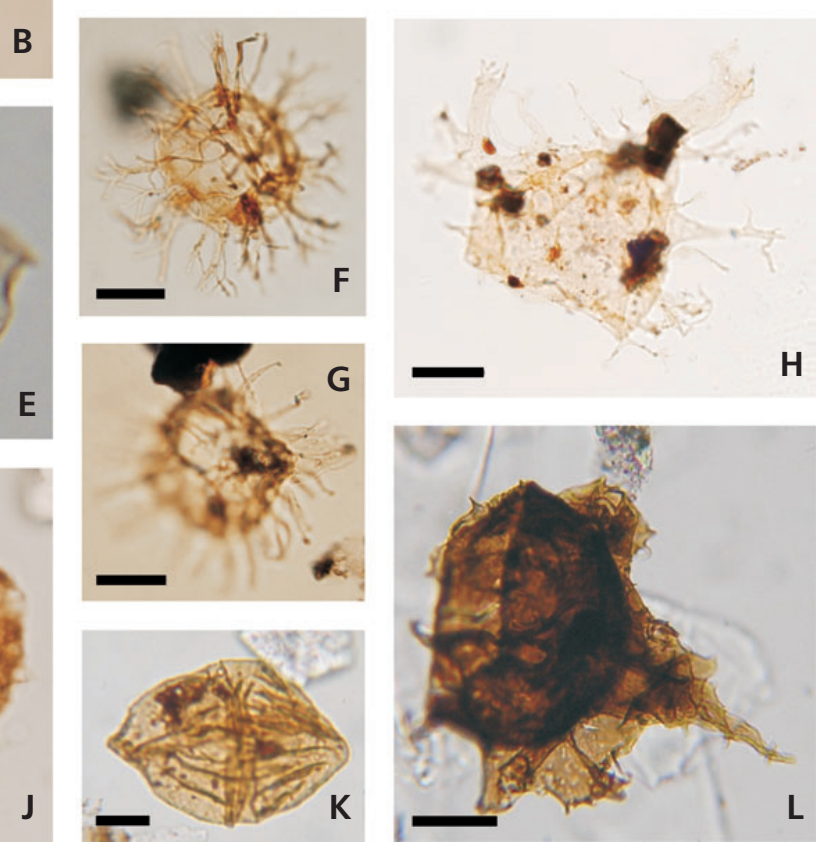

Figure 11. Taxa discovered; the species name is followed by sample location and England Finder coordinates (for localization of the specimen on the slide). Scale is $20 \mu \mathrm{m}$. • A - Tehamadinium sp.; PB3/a, S38. • B - Xenascus ceratioides (Deflandre, 1937b) Lentin \& Williams, 1973 ; SH3a/a, V43/4. - C - Xenascus sp.; SH3b, K/L40.• D - Spiniferites aff. ramosus granosus (Davey \& Williams, 1966a) Lentin \& Williams, 1973 ; SH2/a, Q35/4. - E - Isabelidinium sp.; SH1b, D35. • F - Achomosphaera triangulata (Gerlach, 1961) Davey \& Williams, 1969; PB1a, O37/1. • G - Florentinia radiculata (Davey \& Williams, 1966b) Davey \& Verdier, 1973; BL3a, K44/45. • H - Xenascus sarjeantii (Corradini, 1973) Stover \& Evitt, 1978; PB2/a, S32.・I - Spiniferites ramosus (Ehrenberg, 1838) Loeblich \& Loeblich, 1966; SH2b/a, D50/1. • J - Trithyrodinium evittii Drugg, $1967 ;$ PB2/a, F51/3. - K - Dinogymnium sp.; SH1b, S32/33. • L - Xenascus perforatus (Vozzhennikova, 1967) Yun, 1981 ; PB1b, U37.

\section{Palaeoenvironmental assessment}

The Godula and Istebna Formations represent flysch sedimentation consisting of turbiditic rhythms of relatively coarse-grained clastic material at the base, and fining upwards. Turbiditic material typically originates from the more proximal parts of a flysch basin, e.g., from outer shelf and slope environments. The palynofacies reflect this sedimentation.

Samples are characterized by a very high percentage of phytoclasts (Figs 3-8), a low percentage of palynomorphs (5-10\%) and very little AOM (1-5\%) which indicates a shallow marine environment with high terrestrial influx. Only in the "black" shales of the Istebna Formation (Bílá section) percentage of AOM is slightly higher (10-17\%) and which can indicate anoxic conditions. The studied successions are also characterized by a low percentage of dinoflagellate cysts (less than $9 \%$ ) and a very low percentage of spores and pollen grains (less than 5\%).

Dinoflagellate cyst assemblages in the studied section are dominated by groups, as genera Achomosphaera, Exochosphaeridium, Oligosphaeridium, Pervosphaeridium, Spiniferites and Surculosphaeridium, that lived in offshore waters. However, their ratio is variable. It is the higher in the samples taken from the middle part of the Godula Formation. The occurrence of typical open oceanic dinoflagellates like Pterodinium confirms open marine or oceanic depositional settings.

A general decline in the number of representatives of Achomosphaera, Spiniferites and absence of Pterodinium in the upper part of the Godula Formation and Istebna Formation might be related to sea-level fall.

High flux of organic matter, which seems to be resedimented from more proximal areas, is indicated by the 
Table 3. Distribution of dinoflagellate cysts in the Zarovjanka and Bílá sections. Numbers refer to counted specimens in the slides. Abbreviations: Glap. - Glaphyrocysta, Heterosphae. - Heterosphaeridium, S. - Spiniferites, Surculosphae. - Surculosphaeridium.

\begin{tabular}{|c|c|c|c|c|c|c|}
\hline Age & & Early & y Maa & astricht & $\operatorname{tian}$ & \\
\hline Formation & & Istel & bna Fo & ormati & & \\
\hline Species / Sample Number & ZA1 & ZA2 & BL0 & BL1 & BL2 & BL3 \\
\hline Achomosphaera alcicornu & & & 4 & & & \\
\hline Achomosphaera fenestra & & & 12 & & 12 & 13 \\
\hline Alterbidium acutulum & 11 & & & & & \\
\hline Alterbidinium? distinctum & 14 & & 2 & & & \\
\hline Apteodinium deflandrei & & & & & 2 & \\
\hline Areoligera aff. tenuicapillata & & & 18 & & 12 & \\
\hline Areoligera coronata & & & & & & 15 \\
\hline Areoligera guembelii & & & & & & 14 \\
\hline Areoligera volata & & & 26 & 6 & 31 & 18 \\
\hline Cassiculosphaeridium reticulatum & 12 & & & & & \\
\hline Cauveridium membraniphorum & & & & & & 2 \\
\hline Cerodinium diebelii & 12 & 3 & & 2 & 1 & 16 \\
\hline Cerodinium cf. wardenense & & & 1 & & & \\
\hline Chatangiella sp. & & & 2 & & & 16 \\
\hline Chatangiella williamsii & & & 2 & & & \\
\hline Cordosphaeridium sp. & & & & & 1 & \\
\hline Cyclonephelium filoreticulatum & 2 & & & & & \\
\hline Deflandrea galeata & & & & & & 6 \\
\hline Deflandrea cf. phosphoritica & 16 & & & & & \\
\hline Florentinia ferox & & & & 2 & & \\
\hline Florentinia radiculata & & & & 1 & & 13 \\
\hline Glap. castelcasiense castelcasiense & & & 10 & & & \\
\hline Glaphyrocysta sp. & & 3 & 27 & 2 & & \\
\hline Glaphyrocysta wilsonii & & & 4 & & & \\
\hline Heterosphaeridium cordiforme & & & & & 11 & \\
\hline Heterosphaeridium sp. & & & 42 & & & \\
\hline Heterosphae. spinaconjunctum & & & & & & 12 \\
\hline Homotryblium cf. tenuispinosum & 2 & 1 & & & & \\
\hline Hystrichodinium pulchrum & & & & 2 & & 11 \\
\hline Hystrichosphae. conispiniferum & & & & 12 & & \\
\hline Hystrichosphae. salpingophorum & & & & & 2 & 4 \\
\hline
\end{tabular}

occurrence of dinoflagellate cysts (as genera Areoligera, Odonotochitina), which inhabit mainly near-shore waters. Representatives of Odontochitina are frequent in Godula Formation. Representatives of Areoligera, a genus often associated with inshore environments (Brinkhuis 1994), show the highest frequencies in "black" shales of the Istebna Formation. This might indicate less-open oceanic conditions in the Early Maastrichtian possibly related to a long-term sealevel fall from the Campanian into the Early Maastrichtian.

The constant presence of taxa Cerodinium and Trithyrodinium that indicate tropical conditions (Gedl 2004), indicates rather stable and warm surface waters in the Silesian basin, consistent with the warm temperate or subtropical climate that prevailed during the Late Campanian and Early Maastrichtian.

\begin{tabular}{|c|c|c|c|c|c|c|}
\hline Age & \multicolumn{6}{|c|}{ Early Maastrichtian } \\
\hline Formation & \multicolumn{6}{|c|}{ Istebna Formation } \\
\hline Species / Sample Number & ZA1 & $\mathrm{ZA} 2$ & BL0 & BL1 & BL2 & BL3 \\
\hline Hystrichosphaeridium truswelliae & & & & & 1 & \\
\hline Isabelidinium $\mathrm{sp}$. & 14 & 2 & & & & \\
\hline Kleithriasphaeridium sp. & & & & 5 & & \\
\hline Odontochitina operculata & & & 2 & & & \\
\hline Oligosphaeridium buciniferum & & & 14 & & & \\
\hline Oligosphaeridium complex & 35 & 4 & & & & 7 \\
\hline Oligosphaeridium sp. & & & & & 1 & \\
\hline Operculodinium centrocarpum & & & & 6 & & 3 \\
\hline Operculodinium cf. divergens & & & & 7 & & \\
\hline Palaeocystodinium bulliforme & & & & & & 1 \\
\hline Palaeocystodinium golzowense & 5 & 1 & 13 & 2 & 2 & 3 \\
\hline Palaeoperidinium pyrophorum & & & 2 & 1 & 3 & 1 \\
\hline Pervosphaeridium intervelum & & & 5 & 4 & 1 & 4 \\
\hline Phelodinium kozlowskii & & & & & & $\mathrm{x}$ \\
\hline Phelodinium magnificum & & & & 1 & & \\
\hline Phelodinium tricuspis & & & & & & 1 \\
\hline Pierceites? chiemgoviensis & & & & & 2 & 1 \\
\hline Scriniodinium sp. & 10 & & 2 & & & \\
\hline Senoniasphaera inornata & & & & 2 & & \\
\hline Spiniferites membranaceus & & & & & & 12 \\
\hline Spiniferites pseudofurcatus & & & & & & 1 \\
\hline Spiniferites ramosus & & & 30 & 6 & 2 & 12 \\
\hline S. ramosus granomembranaceus & & & & & & 7 \\
\hline Spiniferites scabrosus & & & & & & 1 \\
\hline Sumatradinium soucouyantiae & & & 1 & 1 & & \\
\hline Surculosphaeridium sp. & 35 & & 4 & & & \\
\hline Surculosphaeridium? cassospinum & & & & & 1 & \\
\hline Surculosphae.? longifurcatum & & 8 & & & & \\
\hline Trithyrodinium sp. & & & 2 & & & \\
\hline Trithyrodinium suspectum & & & 1 & & & \\
\hline Xiphophoridium cf. asteriforme & & & & & 1 & \\
\hline
\end{tabular}

\section{Conclusions}

The palynological study of samples from the Godula and Istebna formations documents the kerogen assemblage and dinoflagellate cysts distribution.

1. Residues are characterized by abundant sedimentary organic materials (SOM), dominated by phytoclasts and containing only a small amount of AOM. The studied successions are also characterized by a low percentage of dinoflagellate cysts (less than 9\%) and a very low percentage of spores and pollen grains (less than 5\%). The former indicates deposition in an offshore marine environment subjected to high influxes of terrestrial material.

2. Dinoflagellate cysts suggest that sedimentation of the middle part of the studied Godula Formation took place 
during the Late Campanian. This is in accordance with data from the Bystrá section (Skupien et al. in press) where dinoflagellate cyst associations of Middle to Late Campanian age occur and occurrence of agglutinated foraminifera confirm this age assignment.

3. Sedimentation of the Godula Formation was terminated close to the Campanian/Maastrichtian boundary or probably during the earliest Maastrichtian.

4. The basal part of the Istebna Formation is of Late Campanian - earliest Maastrichtian age.

5. The dark grey shales of the Istebna Formation were deposited in anoxic conditions (slightly higher percentages of AOM) and are of Early Maastrichtian age.

6. A gradual sea-level fall was presumably responsible for a gradual decrease in the frequency of oceanic taxa from Late Campanian to Early Maastrichtian.

7. The presence of Cerodinium and Trithyrodinium throughout the sections suggests that surface waters were warm.

\section{Acknowledgements}

This research was supported by the Czech Grant Agency No. 205/05/0917 "Upper Cretaceous oceanic red beds in the Czech part of the Outer Western Carpathians; biostratigraphy, sedimentology and geochemistry". We would like to thank Susanne Feist-Burkhardt, Mohamed Ismail Ibrahim, and an anonymous reviewer for reading the manuscript; their critical remarks significantly improved the manuscript.

\section{References}

Antonescu, E., Foucher, J.C., Odin, G.S., Schiøler, P., Siegl-FARKAS, A. \& WILSON, G.J. 2001. Dinoflagellate cysts in the Campanian-Maastrichtian succession of Tercis les Bains (Landes, France), a synthesis, 253-264. In ODIN, G.S. (ed.) The Campanian-Maastrichtian boundary. Elsevier, Amsterdam.

BATTEN, D.J. 1996. Palynofacies and palaeoenvironmental interpretation, 1011-1164. In JANSONIUS, J. \& MCGREGOR, D.C. (eds) Palynology: principles and applications. American Association of Stratigraphic Palynologists Foundation, Dallas.

BRINKHUIS, H. 1994. Late Eocene to Early Oligocene dinoflagellate cysts from the Priabonian type-area (Notheast Italy): biostratigraphy and paleoenvironmental interpretation. $\mathrm{Pa}$ laeogeography, Palaeoclimatology, Palaeoecology 107, 121-163. DOI 10.1016/0031-0182(94)90168-6

CostA, L.I. \& DAVEY, R.J. 1992. Dinoflagellate cyst of the Cretaceous System, 99-132. In POWELL, A.J. (ed.) A stratigraphic index of dinoflagellate cysts. Chapman \& Hall, London.

ELIÁŠ, M. 2000. Relation between Pustevny Sandstone and Malinovska skala Sandstone (Godula Formation) in the Beskydy
Mts. Geologické výzkumy na Moravě a ve Slezsku v roce 1999, 64-66.

FAUCONNIER, D. \& MASURE, E. Eds 2004. Les dinoflagellés fossiles: guide pratique de détermination. Groupe de travail Dinoflagellés. 600 pp. BRGM Ed., Collection Scientifique, Orléans.

Fensome, R.A. \& Williams, G.L. 2004. The Lentin and Williams index of fossil dinoflagellates: 2004 edition. American Association of Stratigraphic Palynologists, Contributions Series $42,909 \mathrm{pp}$.

GEDL, P. 2004. Dinoflagellate cyst record of the deep-sea Cretaceous-Tertiary boundary at Uzgruň, Carpathian Mountains, Czech Republic, 257-273. In OdIN, G.S. (ed.) The Campanian-Maastrichtian boundary. Elsevier, Amsterdam.

HANZLíkovÁ, E. 1972a. Carpathian Upper Cretaceous foraminiferida of Moravia (Turonian-Maastrichtian). Rozpravy Ústředního ústavu geologického 39, 1-160.

HANZLíKOVÁ, E. 1972b. Mikropaläontologische Zoneneinteilung und Stratigraphie der Istebna-Schichten und ihres unmittelbaren Hangenden. Věstník Ústředního ústavu geologického 47(2), 69-77.

HANZLíKOVÁ, E. 1973. Foraminifera of the variegated Godula Member in Moravia (Cenomanian-Turonian). Sborník geologických věd, Paleontologie 15, 119-184.

Hoek, R.P., Eshet, Y. \& Almogi-Labin, A. 1996. Dinoflagellate cyst zonation of Campanian-Maastrichtian sequences in Israel. Micropaleontology 42, 125-150.

DOI $10.2307 / 1485866$

KIRSCH, K.H. 1991. Dinoflagellatenzysten aus der Oberkreide des Helvetikums und Nordultrahelvetikums von Oberbayern. Münchner Geowissenschaftliche Abhhandlungen, Reihe A, Geologie und Paläontologie 22, 1-306.

LEMAŇSKA, A. \& GEDL, P. 2005. Benthic agglutinated foraminifera and organic-walled dinoflagellate cysts from Late Cretaceous oceanic deposits at Kalwaria Zebrzydowska, Flysch Carpathians, Poland: biostratigraphy and palaeoenvironment. Slovak Geological Magazine 11(1), 45-58.

LISTER, J.K. \& BATTEN, D.J. 1988. Stratigraphic and palaeoenvironmental distribution of Early Cretaceous dinoflagellate cysts in the Hurlands Farm borehole, west Sussex, England. Palaeontographica, Abteilung B 210, 9-89.

MATĚJKA, A. 1949. Geologická studie z okolí Valašského Meziříčí. Sborník Státního geologického ústavu 16, 643-693.

MATĚJKA, A. 1952. Contribution to the geology of the basin of the Horní Ostravice in the Moravskoslezské Beskydy. Sborník Státního geologického ústavu 19, 621-646.

MENČíK, E., ADAMOVÁ, M., DVOŘÁK, J., DUDEK, A., JETEL, J., Jurková, A., HANZlíková, E., Houša, V., Peslová, H., RYBÁR̆OVÁ, L., ŠMÍD, B., ŠEBESTA, J., TYRÁČEK, J. \& VAŠÍČEK, Z. 1983. Geology of the Moravskoslezské Beskydy and Podbeskydy upland. 304 pp. Ústřední ústav geologický, Praha (in Czech).

PÍCHA, E.J., STRÁNíK, Z. \& KREJČí, O. 2006. Geology and hydrocarbon resources of the Outer Western Carpathians and their foreland, Czech Republic, 49-175. In GoLONKA, J. \& PíCHA, F.J. (eds) The Carpathians and their foreland: Geol- 
ogy and hydrocarbon resources. American Association of Petroleum Geologists Memoir 84.

RoBASZYNSKI, F., BLESS, M.J.M., FELDER, P.J., FOUCHER, J.C., LegouX, O., MANivit, H., MEEssen, J. \& VAN DeR TuUK, L.A. 1985. The Campanian-Maastrichtian boundary in the chalky facies close to the type-Maastrichtian area. Bulletin des Centres de Recherches Exploration-Production Elf-Aquitaine 9(1), 1-252.

RonCAGLIA, L. 2002. Lower Maastrichtian dinoflagellates from the Viano Clays Formation at Viano, northern Apennines, Italy. Cretaceous Research 23, 65-76.

DOI 10.1006/cres.2002.0298

RonCAGLiA, L. \& CoRRADINI, D. 1997. Upper Campanian to Maastrichtian dinoflagellate zonation in the northern Apennines, Italy. Newsletters on Stratigraphy 35(1), 29-57.

RоTH, Z. 1980. Západni Karpaty - terciérni struktura středni Evropy. 128 pp. Knihovna Ústředního ústavu geologického, Praha.

SKUPIEN, P. 1999. Dinoflagellate cysts distribution of AlbianCenomanian sections from the Outer Western Carpathians. Věstník Českého geologického ústavu 74(1), 1-10.

SKUPIEN, P. 2003. A summary of palynological results of the study of the lower part of the Silesian Unit (Czech part of the Outer Western Carpathians). Transactions of the V $\breve{S} B-$ Technical University Ostrava, Mining and Geological Series, Monograph 8, 107-116 (in Czech).

SKUPIEN, P. \& VAŠÍČEK, Z. 2003. Lithostratigraphical and biostratigraphical knowledge of the Bystrý potok section by Frenštát p. R. (Upper Cretaceous, Silesian Unit of the Outer Western Carpathians). Transactions of the V $\breve{S} B$ - Technical University Ostrava, Mining and Geological Series, Monograph 8, 64-94 (in Czech).
Skupien, P., Bubík, M., ŠvábenickÁ, L., Mikuláš, R., VAŠ́́ČEK, Z. \& MATÝSEK, D. in press. Cretaceous Oceanic Red Beds in the Outer Western Carpathians of Czech Republic. SEPM Special Publication.

SMelRoR, M. \& LEEREVElD, H. 1989. Dinoflagellate and acritarch assemblages from the Late Bathonian to Early Oxfordian of Montagne Crussol, Rhone Valley, southern France. Palynology 13, 121-141.

StOVER, L.E., BrinKHUIS, H., DAMASSA, S.P., DE VERTEUIL, L., Helby, R.J., Monteil, E., PARTRIdGe, A.D., Powell, A.J., RIDING, J.B., SMELROR, M. \& WILLIAMS, G.L. 1996. Chapter 19. Mesozoic-Tertiary dinoflagellates, acritarchs and prasinophytes, 641-750. In JANSONIUS, J. \& MCGREGOR, D.C. (eds) Palynology: principles and applications. American Association of Stratigraphic Palynologists Foundation, Salt Lake City.

TORRICELLI, S. \& AMORE, M.R. 2003. Dinoflagellate cysts and calcareous nannofossils from the Upper Cretaceous Saraceno Formation (Calabria, Italy): implication about the history of the Liguride Complex. Rivista Italiana di Paleontologia e Stratigrafia 109(3), 499-516.

TYSON, R.V. 1995. Sedimentary organic matter. Organic facies and palynofacies. 615 pp. Chapman \& Hall, London.

Williams, G.L., BRINKHUis, H., PEARCE, M.A, FENSOME, R.A. \& WeEGINK, J.W. 2004. Southern ocean and global dinoflagellate cyst events compared: Index events for the late Cretaceous-Neogene, 1-98. In EXON, N.F., KENNETT, J.P. \& Malone, M.J. (eds) Proceedings of the Ocean Drilling Program, Scientific Results 189.

YPES, O. 2001. Maastrichtian-Danian dinoflagellate cyst biostratigraphy and biogeography from two equatorial sections in Colombia and Venezuela. Palynology 25, 217-249. DOI $10.2113 / 0250217$

\section{Appendix. List of dinocyst taxa encountered in this study}

List of dinocyst taxa encountered in this study, arranged in alphabetical order of genus name. The readers are referred to Fensome \& Williams (2004) and Fauconnier \& Masure (2004) for dinocyst taxonomy and references to taxa. A selection of taxa is depicted on Figs 9-11.

Achomosphaera alcicornu (Eisenack, 1954b) Davey \& Williams, 1966

Achomosphaera andalousiensis Jan du Chêne, 1977

Achomosphaera fenestra Kirsch, 1991

Achomosphaera ramulifera (Deflandre, 1937b) Evitt, 1963

Achomosphaera ramulifera ramosasimilis Yun, 1981

Achomosphaera sagena Davey \& Williams, 1966

Achomosphaera triangulata (Gerlach, 1961) Davey \& Williams, 1969

Alterbidium acutulum (Wilson, 1967b) Lentin \& Williams, 1985

Alterbidinium? distinctum (Wilson, 1967) Lentin \& Williams, 1985
Alterbidinium ulloriaq Nøhr-Hansen, 1996

Apteodinium deflandrei (Clarke \& Verdier, 1967) Lucas-Clark, 1987

Areoligera coronata (O. Wetzel, 1933a) Lejeune-Carpentier, 1938 Areoligera guembelii Kirsch, 1991

Areoligera senonensis Lejeune-Carpentier, 1938

Areoligera aff. tenuicapillata (O. Wetzel, 1933) Lejeune-Carpentier, 1938

Areoligera volata Drugg, 1967

Biconidinium longissimum Islam, 1983

Callaiosphaeridium asymmetricum (Deflandre \& Courteville, 1939) Davey \& Williams, 1966

Cassiculosphaeridium reticulatum Davey, 1969

Cauveridium membraniphorum (Cookson \& Eisenack, 1962)

Fauconnier \& Masure, 2004

Cerebrocysta bartonensis Bujak in Bujak et al., 1980

Cerodinium diebelii (Alberti, 1959b) Lentin \& Williams, 1987 
Cerodinium cf. wardenense (Williams \& Downie, 1966) Lentin \& Williams, 1987

Cerodinium sp.

Chatangiella bondarenkoi (Vozzhennikova, 1967) Lentin \& Williams, 1976

Chatangiella sp.

Chatangiella spectabilis (Alberti, 1959b) Lentin \& Williams, 1976

Chatangiella tripartita (Cookson \& Eisenack, 1960a) Lentin \& Williams, 1976

Chatangiella williamsii Yun, 1981

Cordosphaeridium sp.

Coronifera oceanica hebospina Yun, 1981

Cribroperidinium cf. edwardsii (Cookson \& Eisenack, 1958) Davey, 1969

Cribroperidinium orthoceras (Eisenack, 1958a) Davey, 1969

Cyclonephelium distinctum Deflandre \& Cookson, 1955

Cyclonephelium filoreticulatum (Slimani, 1994) Prine et al., 1999

Dapsillidinum duma (Below, 1982) Lentin \& Williams, 1985

Deflandrea galeata (Lejeune-Carpentier, 1942) Lentin \& Williams, 1973

Deflandrea cf. phosphoritica Eisenack, 1938

Dinogymnium sp.

Dinogymnium cf. sibiricum (Vozzhennikova, 1967) Lentin \& Williams, 1973

Downiesphaeridium? aciculare (Davey, 1969a) Fauconnier \& Masure, 2004

Ellipsodinium rugulosum Clarke \& Verdier, 1967

Exochosphaeridium aff. bifidum (Clarke \& Verdier, 1967) Clarke et al., 1968

Exochosphaeridium bifidum (Clarke \& Verdier, 1967) Clarke et al., 1968

Exochosphaeridium multifurcatum (Deflandre, 1937b) Fauconnier \& Masure, 2004

Exochosphaeridium phragmites Davey et al., 1966

Exochosphaeridium sp.

Florentinia aculeata Kirsch, 1991

Florentinia deanei (Davey \& Williams, 1966b) Davey \& Verdier, 1973

Florentinia ferox (Deflandre, 1937b) Duxbury, 1980

Florentinia hypomagna Yun, 1981

Florentinia laciniata Davey \& Verdier, 1973

Florentinia cooksoniae (Singh, 1971) Duxbury, 1980

Florentinia radiculata (Davey \& Williams, 1966) Davey \& Verdier, 1973

Florentinia sp.

Glaphyrocysta castelcasiensis castelcasiensis Corradini, 1973

Glaphyrocysta sp.

Glaphyrocysta texta (Bujak, 1976) Stover \& Evitt, 1978

Glaphyrocysta wilsonii Kirsch, 1991

Hafniasphaera fluens Hansen, 1977

Heteraulacacysta porosa Bujak in Bujak et al., 1980

Heterosphaeridium cordiforme Yun, 1981

Heterosphaeridium sp.

Heterosphaeridium spinaconjunctum Yun, 1981

Homotryblium cf. tenuispinosum Davey \& Williams, 1966

Hystrichodinium pulchrum Deflandre, 1935

Hystrichokolpoma proprium (Marheinecke, 1992) Foucher, 2004
Hystrichosphaeridium bowerbankii Davey \& Williams, 1966

Hystrichosphaeridium conispiniferum Yun, 1981

Hystrichosphaeridium salpingophorum Deflandre, 1935

Hystrichosphaeridium truswelliae Wrenn \& Hart, 1988

Hystrichosphaeridium tubiferum (Ehrenberg, 1838) Deflandre, 1937

Hystrichosphaeridium? sp.

Hystrichostrogylon membraniphorum Agelopoulos, 1964

Isabelidinium belfastense (Cookson \& Eisenack, 1961) Lentin \&

Williams, 1977

Isabelidinium cf. bakeri (Deflandre \& Cookson, 1955) Lentin \& Williams, 1977

Isabelidinium $\mathrm{sp.}$

Isabelidinium svartenhukensis Nøhr-Hansen, 1996

Kiokansium polypes (Cookson \& Eisenack, 1962) Below, 1982

Kleithriasphaeridium loffrense Davey \& Verdier, 1976

Kleithriasphaeridium readii (Davey \& Williams, 1966) Davey \&

Verdier, 1976

Kleithriasphaeridium sp.

Leberidocysta chlamydata (Cookson \& Eisenack, 1962b) Stover \& Evitt, 1978

Multiplicisphaeridium? cruciatum (Wetzel, 1933) Stancliffe \& Sarjeant, 1994

Odontochitina costata Alberti, 1961

Odontochitina operculata (O. Wetzel, 1933) Deflandre \& Cookson, 1955

Odontochitina porifera Cookson, 1956

Oligosphaeridium albertense (Pockock, 1962) Davey \& Williams, 1969

Oligosphaeridium asterigerum (Gocht, 1959) Davey \& Williams, 1969

Oligosphaeridium buciniferum Corradini, 1973

Oligosphaeridium complex (White, 1842) Davey \& Williams, 1966

Oligosphaeridium poculum Jain, 1977

Oligosphaeridium sp.

Operculodinium centrocarpum (Deflandre \& Cookson, 1955) Wall, 1967

Operculodinium cf. divergens (Eisenack, 1954b) Stover \& Evitt, 1978

Palaeocystodinium bulliforme Ioannides, 1986

Palaeocystodinium golzowense Alperti, 1961

Palaeohystrichophora infusorioides Deflandre, 1935

Palaeoperidinium pyrophorum (Ehrenberg, 1838) Sarjeant, 1967

Palaeoperidinium sp.

Palaeotetradinium silicorum Deflandre, 1936

Pervosphaeridium intervelum Kirsch, 1991

Pervosphaeridium pseudhystricodinium (Deflandre, 1937) Yun, 1981

Pervosphaeridium truncatum (Davey, 1969) Below, 1982

Phelodinium cf. kozlowskii (Gorka, 1963) Lindgren, 1984

Phelodinium magnificum (Stanley, 1965) Stover \& Evitt, 1978

Phelodinium tricuspe (O. Wetzel, 1933) Stover \& Evitt, 1978

Phthanoperidinium distinctum Bujak, 1994

Pierceites? chiemgoviensis Kirsch, 1991

Pierceites cf. schizocystis Habib \& Drugg, 1987

Pterodinium aliferum Eisenack, 1958

Pterodinium cingulatum (O. Wetzel, 1933b) Below, 1981

Pterodinium? cornutum Eisenack, 1958 
Raetiaedinium truncigerum (Deflandre, 1937) Kirsch, 1991

Scriniodinium? sp.

Senoniasphaera inornata (Drugg, 1970) Stover \& Evitt, 1978

Senoniasphaera rotundata Clarke \& Verdier, 1967

Spiniferites aff. ramosus granosus (Davey \& Williams, 1966)

Lentin \& Williams, 1973

Spiniferites cf. bulloideus (Deflandre \& Cookson, 1955) Sarjeant, 1970

Spiniferites membranaceus (Rossignol, 1964) Sarjeant, 1970

Spiniferites porosus (Manum \& Cookson, 1964) Harland, 1973

Spiniferites pseudofurcatus (Klumpp, 1953) Sarjeant, 1970

Spiniferites ramosus granomembranaceus (Davey \& Williams,

1966a) Lentin \& Williams, 1973

Spiniferites ramosus (Ehrenberg, 1838) Loeblich \& Loeblich, 1966

Spiniferites ramosus brevifurcatus (Eisenack \& Cookson, 1974)

Lentin \& Williams, 1977

Spiniferites scabrosus (Clarke \& Verdier, 1967) Lentin \& Williams, 1975
Spiniferites? velatus (Clarke \& Verdier, 1967) Stover \& Evitt, 1978 Subtilisphaera sp.

Sumatradinium soucouyantiae de Verteuil \& Norris, 1992

Surculosphaeridium sp.

Surculosphaeridium? cassospinum Yun, 1981

Surculosphaeridium? longifurcatum (Firtion, 1952) Davey et al., 1966

Tehamadinium sp.

Tanyosphaeridium boletus Davey, 1974

Thalassiphora sp.

Trithyrodinium evittii Drugg, 1967

Trithyrodinium sp.

Trithyrodinium suspectum (Manum \& Cookson, 1964) Davey, 1969

Xenascus ceratioides (Deflandre, 1937) Lentin \& Williams, 1973

Xenascus perforatus (Vozzhennikova, 1967) Yun, 1981

Xenascus sarjeantii (Corradini, 1973) Stover \& Evitt, 1978

Xenascus sp.

Xiphophoridium cf. asteriforme Yun, 1981 